\begin{abstract}
ANNA ŁASIŃSKA
ORCID: 0000-0002-0233-0885

DOI: $10.4467 / 20801335$ PBW.21.002.13559

\section{Analiza SEM czarnego tonera na wydrukach. Część II}

Wykrycie, że dokument generowany komputerowo został sfałszowany, zawsze było wyzwaniem dla śledczych i biegłych w zakresie kryminalistycznych badań dokumentów. $\mathrm{Z}$ punktu widzenia kryminalistyki istotna wydaje się analiza autentyczności takiego dokumentu, m.in. identyfikacja urządzenia wykonawczego. W ciągu ostatnich dwóch lat ukazało się niewiele publikacji na temat analizy wydruków $\mathrm{z}$ laserowych urządzeń wykonawczych. W celu wsparcia procesów badawczych Neha Verma i inni naukowcy zaproponowali zastosowanie techniki skaningowej mikroskopii elektronowej z emisją polową Schottky’ego zintegrowaną $\mathrm{z}$ energodyspersyjną spektroskopią rentgenowską (FE-SEM-EDS) jako najnowszego narzędzia do analizy czarnych tonerów wykorzystanych w drukarkach laserowych i kserokopiarkach ${ }^{1}$. Badania przeprowadzono pod kątem określenia cech morfologicznych tonerów, ich wielowymiarowej analizy oraz określenia ich składu pierwiastkowego. Analiza wielowymiarowa posłużyła autorom do opracowania „modelu klasyfikacji” wydruków na podstawie składu chemicznego tonerów. Z kolei Raj Kumar i inni zastosowali metodę ATR-FTIR², łącząc ją z metodami chemometrycznymi w celu szybkiej i nieniszczącej analizy wydruków z urządzeń laserowych oraz dokumentów drukowanych za pomocą drukarek atramentowych ${ }^{3}$. Autorzy podjęli

1 N. Verma i in., On the spectroscopic examination of printed documents by using a field emission scanning electron microscope with energy-dispersive X-ray spectroscopy (FE-SEM-EDS) and chemometric methods: application in forensic science, "Analytical and Bioanalytical Chemistry” 2019, nr 16, s. 3477-3495.

2 Spektroskopia osłabionego całkowitego odbicia w podczerwieni.

3 R. Kumar, A. Samkaria, V. Sharma, On the spectroscopic cum chemometric approach for differentiation and classification of inkjet, laser and photocopier printed documents, „Science \& Justice” 2020, nr 4, s. 347-357. 
się ustalenia źródła pochodzenia nieznanych dokumentów oraz wizualizacji zmian wewnętrznych występujących w tych samych typach drukowanych dokumentów.

Celem niniejszej publikacji jest wskazanie możliwości identyfikacyjnych urządzeń wykonawczych i ocena tych możliwości na podstawie uzyskanych wydruków. Praca jest kontynuacją dwóch publikacji, które ukazały się w latach 2018-20194. Do badań opublikowanych we wskazanych artykułach wykorzystano wydruki wykonane przy użyciu oryginalnych tonerów oraz ich zamienników. Przedstawione obrazy ze skaningowego mikroskopu elektronowego pozwoliły na przyporządkowanie charakterystycznych cech tonerów do poszczególnych grup urządzeń, tj. monochromatycznych drukarek laserowych, kolorowych drukarek laserowych, monochromatycznych urządzeń wielofunkcyjnych oraz kolorowych urządzeń wielofunkcyjnych. Na podstawie ustalonych kryteriów oceny indywidualnej posegregowano cechy szczególne tonerów na wydrukach uzyskanych $\mathrm{z}$ danego urządzenia drukującego i powielającego oraz nadano im nazwy. Kontynuując eksperyment, w niniejszym artykule zamieszczono wyniki badań wydruków uzyskanych z laserowych urządzeń drukujących dwóch firm: Brother oraz Konica Minolta.

Zakup aparatury analitycznej oraz badania zaprezentowane $\mathrm{w}$ niniejszej publikacji zostały zrealizowane w ramach projektu badawczego nr 0023/R/ID3/2012/02, finansowanego ze środków Narodowego Centrum Badań i Rozwoju.

\section{Materiały i metody}

\section{Materiat badawczy}

Badanie przeprowadzono na 21 wydrukach stron testowych $\mathrm{z}$ drukarek laserowych oraz laserowych urządzeń wielofunkcyjnych firm Brother i Konica Minolta. Wszystkie wydruki wykonano na papierze formatu A4 jednego rodzaju (standardowym kserograficznym) firmy Papyrus. Zgodnie z zapewnieniami producenta jest to papier bezdrzewny, biały, niepowlekany, matowy. Szesnaście wydruków wykonano przy użyciu oryginalnych tonerów, a pięć przy użyciu zamienników tonerów. Zamienniki „Tonery Laser Experts" pochodziły od jednego dystrybutora - firmy Jet-printer. Przeprowadzono badania jedynie nadruków czarnych. Ocenie poddano powierzchnie tych samych znaków (o, n, u) lub (E, F, G). Na każdym wydruku analizowano po trzy litery z początku, środka i końca tekstu - w sumie dziewięć liter. Każdą literę oglądano w kilku miejscach: na zaokrągleniach, brzegach, rogach i w miejscu połączeń części liter. Wydruki uzyskano z czterech typów urządzeń: kolorowych drukarek laserowych, monochromatycznych drukarek laserowych, kolorowych laserowych urządzeń wielofunkcyjnych

4 A. Lasińska, Assessment of the possibility of identification of black toners on printouts in Lexmark printers using SEM method, „Journal of Microscopy and Ultrastructure” 2018, $6 \mathrm{nr}$ 3, s. 145-159; taż, Analiza SEM czarnego tonera na wydrukach. Część I, „Przegląd Bezpieczeństwa Wewnętrznego" 2019, nr 21, s. 211-246. 
oraz monochromatycznych laserowych urządzeń wielofunkcyjnych. Wyniki badań oryginalnych tonerów przedstawiono w tabeli 1, a zamienników - w tabeli 2.

Tab. 1. Testowane urządzenia drukujące Brother oraz Konica Minolta - oryginalny toner ${ }^{5}$.

\begin{tabular}{|c|c|c|}
\hline Lp. & MODEL & TYP URZĄDZENIA \\
\hline \multicolumn{3}{|c|}{ Brother } \\
\hline 1. & HL-2240 & \multirow{3}{*}{ monochromatyczne drukarki laserowe } \\
\hline 2. & HL-2250DN & \\
\hline 3. & HL-7050 & \\
\hline 4. & DCP-9042CDN & \multirow{2}{*}{$\begin{array}{l}\text { kolorowe laserowe urządzenia } \\
\text { wielofunkcyjne }\end{array}$} \\
\hline 5. & MFC-L9570CDW & \\
\hline 6. & DCP-7055W & \multirow{2}{*}{$\begin{array}{l}\text { monochromatyczne laserowe } \\
\text { urządzenia wielofunkcyjne }\end{array}$} \\
\hline 7. & DCP-7057E & \\
\hline \multicolumn{3}{|c|}{ Konica Minolta } \\
\hline 8. & Bizhub c35 & kolorowe drukarki laserowe \\
\hline 9. & Bizhub c25 & \multirow{5}{*}{$\begin{array}{l}\text { kolorowe laserowe urządzenia } \\
\text { wielofunkcyjne }\end{array}$} \\
\hline 10. & Bizhub 42 & \\
\hline 11. & Bizhub c224 & \\
\hline 12. & Bizhub c552 & \\
\hline 13. & Bizhub c754 & \\
\hline 14. & Bizhub 283 & \multirow{3}{*}{$\begin{array}{l}\text { monochromatyczne laserowe } \\
\text { urządzenia wielofunkcyjne }\end{array}$} \\
\hline 15. & Bizhub 501 & \\
\hline 16. & Bizhub 552 & \\
\hline
\end{tabular}

Tab. 2. Testowane urządzenia drukujące Brother oraz Konica Minolta - zamienniki.

\begin{tabular}{|c|c|c|}
\hline Lp. & MODEL & TYP URZĄDZENIA \\
\hline \multicolumn{3}{|c|}{ Brother } \\
\hline 1. & HL-2150N & \multirow{2}{*}{ monochromatyczne drukarki laserowe } \\
\hline 2. & HL-2250DN & \\
\hline 3. & DCP9010CN & kolorowe laserowe urządzenia wielofunkcyjne \\
\hline \multicolumn{3}{|c|}{ Konica Minolta } \\
\hline 4. & Bizhub c35 & kolorowe drukarki laserowe \\
\hline 5. & Bizhub c25 & kolorowe laserowe urządzenia wielofunkcyjne \\
\hline
\end{tabular}

\footnotetext{
5 Wszystkie zdjęcia i tabele zostały opracowane przez autorkę tekstu (przyp. red.).
} 
W celu ustalenia cech budowy charakterystycznych dla konkretnego tonera wykorzystano skaningowy mikroskop elektronowy (SEM). Sposób przeprowadzenia obrazowania mikroskopowego oraz przygotowania preparatów zostały dokładnie opisane w części artykułu. Podobnie jak poprzednio, przyjęto ustalone kryteria oceny i weryfikacji tonera naniesionego na papier, do których zaliczono:

1) sposób rozłożenia warstwy tonera na wydruku (lita czy ziarnista),

2) cechy charakterystyczne struktury powierzchni tonera,

3) cechy charakterystyczne sposobu rozłożenia ziaren tonera,

4) wielkość kształt ziaren oraz strukturę powierzchni ziaren.

\section{Powtarzalność}

W celu sprawdzenia powtarzalności otrzymanych wyników przeanalizowano wydruki uzyskane z urządzenia Brother MFC-L9570CDW, w którym zastosowano oryginalny toner. Z każdego wydruku pobrano sześć próbek i oddzielnie je przeanalizowano metodą skaningowej mikroskopii elektronowej. Ocenie poddano kilka cech charakterystycznych, m.in. nieregularne i regularne struktury na ziarnach i powierzchni litej oraz kształt ziaren. Okazało się, że mikrostruktura tonera jest taka sama na wszystkich wydrukach pochodzących $\mathrm{z}$ tego samego modelu urządzenia drukującego. Za każdym razem na wydrukach zaobserwowano identyczny efekt - taki sam kształt i wielkość ziaren oraz takie same struktury pojawiające się w ziarnach lub na ich powierzchni.

\section{Badania tonerów na podłożach papierowych o dwóch różnych gramaturach}

Oryginalny toner przeznaczony do urządzenia Brother MFC-L9570CDW naniesiono na dwa rodzaje arkuszy papieru o różnej gramaturze dostępnych w handlu. Toner został naniesiony na papier firmy Papyrus formatu A4 o następujących gramaturach: $80 \mathrm{~g} / \mathrm{m}^{2}$ (papier niepowlekany) oraz $199 \mathrm{~g} / \mathrm{m}^{2}$ (papier powlekany). Przed rozpoczęciem serii badań przeprowadzono testy w celu wyeliminowania ewentualnych cech pochodzących z napylania warstwą grafitu. Badano próbki liter bez napylonej powłoki. Następnie próbki pojedynczych liter wyciętych z wydruków były napylane grafitem. Stwierdzono, że rodzaj podłoża wpływa w pewnym zakresie na rozkład tonera.

$\mathrm{Na}$ wydrukach uzyskanych na obu typach papieru toner charakteryzował się obecnością części ziarnistej i litej. Najwięcej strefy ziarnistej i pojedynczych ziaren obserwowano na papierze o gramaturze $80 \mathrm{~g} / \mathrm{m}^{2}$. Na całej powierzchni litej był widoczny wyraźny zarys kształtu ziaren. Natomiast na papierze o gramaturze $199 \mathrm{~g} / \mathrm{m}^{2}$ strefa ziarnista była znacznie mniejsza. Ziarna i grupy połączonych ziaren występowały nielicznie w małych skupiskach wewnątrz linii nadruku i w niewielkiej ilości po zewnętrznych stronach linii wydruku. Na powierzchni litej można było zobaczyć wiele pęknięć powierzchni tonera oraz nawarstwienia, które przysłaniały powierzchnie $\mathrm{z}$ widocznymi zarysami kształtu ziaren. Gdzieniegdzie obserwowano również struktury o kształtach nieregularnych (zdj. 1). 

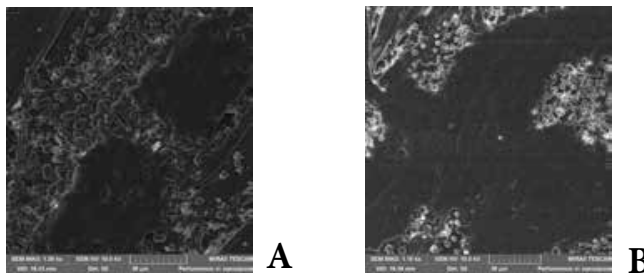

Zdj. 1. Struktura powierzchni litej wydruków uzyskanych $\mathrm{z}$ urządzenia Brother MFC-L-9570CDW. Wydruk na papierze o gramaturze $80 \mathrm{~g} / \mathrm{m}^{2}$ - powiększenie $1280 \times(\mathrm{A})$, wydruk na papierze o gramaturze $199 \mathrm{~g} / \mathrm{m}^{2}$ - powiększenie $1160 \times(B)$.

Na obu typach papieru zostały zachowane cechy szczególne ziaren oraz powierzchni litej. Ziarna miały kształt sferyczny, a na ich powierzchni obserwowano struktury guzkowate oraz nieliczne struktury o nieregularnych kształtach. Wraz ze wzrostem grubości papieru obserwowano więcej powierzchni stopionej i litej, przy zachowaniu jednocześnie cech wewnętrznych, tzn. wszystkich cech oprócz cech zmiennych, jakimi są rozkład i wartość stosunku strefy ziarnistej do litej.

\section{Wyniki i dyskusja}

\section{Oryginalny toner}

\section{Laserowe urządzenia drukujące firmy Brother}

$\mathrm{Na}$ wydrukach uzyskanych z trzech modeli monochromatycznych drukarek laserowych zaobserwowano zarówno cechy wspólne, jak i istotne różnice w sposobie rozłożenia warstwy tonera na papierze (zakres powiększeń 100-150x). Powierzchnię tonera tworzyła głównie warstwa lita. Na wydruku uzyskanym z modelu HL-2240 (zdj. 2 A i B) obszar powierzchni litej był przerywany mniejszymi lub większymi obszarami w postaci pustych otworów (dziur), obszarów wypełnionych pojedynczymi ziarnami bądź grupami ziaren połączonych ze sobą większą lub mniejszą częścią powierzchni i tworzących aglomeraty. Warstwa lita była pofałdowana, zawierała liczne załamania i pęknięcia powierzchni mającej nieregularny kształt i ostre krawędzie. Na powierzchni litej tonera były widoczne również liczne struktury o nieregularnych kształtach i różnych wielkościach. Występowały też obszary, w których można było dostrzec zarysy ziaren wtopionych $\mathrm{w}$ powierzchnię tonera, głównie na granicy przejścia powierzchni litej w ziarnistą. Wydruki uzyskane z modelu HL-2250DN (zdj. 2 C i D) charakteryzowały się podobnymi cechami powierzchni litej tonera. Różnica polegała jedynie na tym, że powierzchnia lita zawierała dodatkowo obszary gładkie, czego nie zaobserwowano na wydrukach z modelu HL-2240. W przypadku wydruków uzyskanych z modelu HL-7050 (zdj. 2 E i F), w odróżnieniu od obu wcześniej opisanych modeli, powierzchnia lita tonera była przerywana nielicznymi mniejszymi lub większymi obszarami ziarnistymi. Poza tym była pofałdowana, zawierała liczne pęknięcia oraz dziury 
niewypełnione ziarnami. Na powierzchni litej było widać zarysy ziaren wtopionych w powierzchnię i ściśle ze sobą połączonych, tworzących zwartą warstwę tonera.
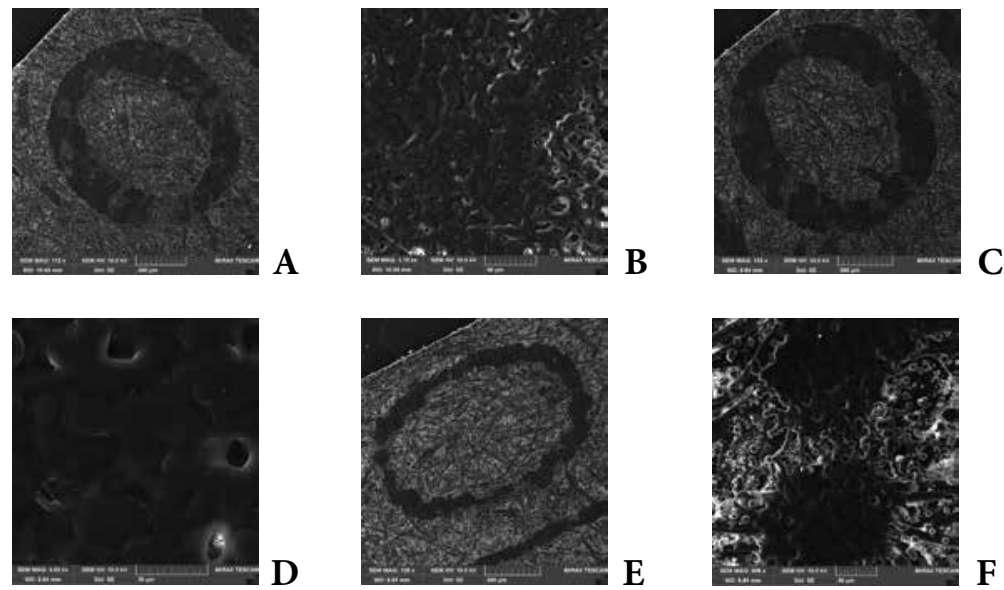

Zdj. 2. Obrazy SEM powierzchni litej tonerów dla wydruków wytworzonych z modeli: HL-2240 - powiększenie $112 \times(\mathrm{A})$, powiększenie 1150× (B); HL-2250DN - powiększenie 123× (C), powiększenie 4030× (D); HL-7050 - powiększenie 125× (E), powiększenie 906× (F).

W grupie kolorowych laserowych urządzeń wielofunkcyjnych analizie poddano wydruki uzyskane $\mathrm{z}$ dwóch modeli urządzeń drukujących: DCP-9042CDN oraz MFC-L9570CDW. Na wydrukach uzyskanych z modelu DCP-9042CDN (zdj. 3 A i B) nie zaobserwowano typowej powierzchni litej. Przypominała ona raczej powierzchnię ziarnistą, były na niej wyraźnie widoczne zarysy ziaren wtopionych w powierzchnię i ściśle ze sobą połączonych, tworzących zwartą warstwę tonera. Na wydrukach uzyskanych z modelu MFC-L9570CDW (zdj. 3 C i D) warstwę tonera tworzyły struktury: ziarnista oraz lita. Warstwa lita, przerywana licznymi mniejszymi lub większymi obszarami o strukturze ziarnistej, była pofałdowana, z licznymi wgłębieniami oraz pojedynczymi dziurami. Na powierzchni warstwy można było wyraźnie zobaczyć zarysy ziaren stopionych i połączonych ze sobą.
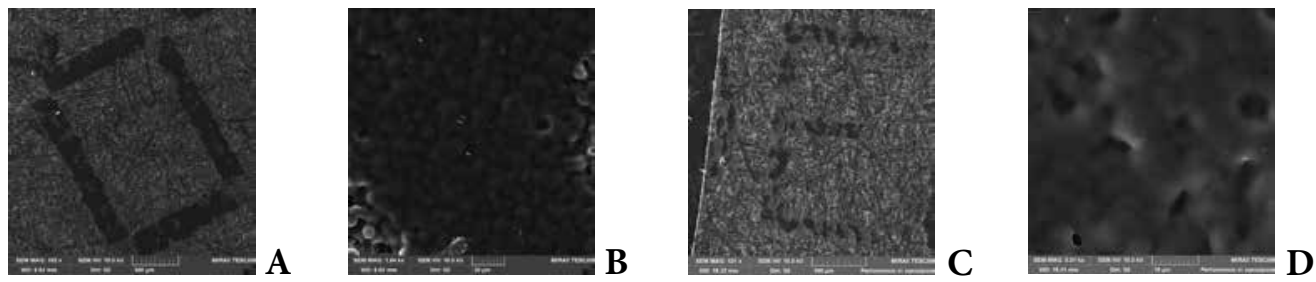

Zdj. 3. Obrazy SEM powierzchni litej tonerów dla wydruków wytworzonych z modeli: DCP-9042CDN - powiększenie 103× (A), powiększenie 1840× (B); MFC-L9570CDW - powiększenie $121 \times(\mathrm{C})$, powiększenie $5210 \times(\mathrm{D})$. 
Trzecią grupę badanych urządzeń drukujących stanowiły monochromatyczne laserowe urządzenia wielofunkcyjne. Obrazowaniu poddano wydruki $z$ dwóch dostępnych modeli tego typu urządzeń. Na wydrukach z modelu DCP-7055W (zdj. 4 A i B) warstwę tonera tworzyły strefy lita i ziarnista. Warstwa lita była przerywana licznymi mniejszymi lub większymi obszarami powierzchni ziarnistej, a także licznymi obszarami w postaci pustych otworów (dziur), obszarów wypełnionych pojedynczymi ziarnami bądź grupami ziaren połączonych ze sobą większą lub mniejszą częścią powierzchni i tworzących aglomeraty. Powierzchnia lita była pofałdowana, z wyraźnie widocznym zarysem ziaren, stopionych i ściśle ze sobą połączonych. W przypadku wydruków uzyskanych z modelu DCP-7057E (zdj. 4 C i D) powierzchnia wydruku pojedynczej litery stanowiła głównie litą warstwę tonera. Była ona przerywana nielicznymi obszarami wypełnione pojedynczymi ziarnami lub grupami ziaren połączonych ze sobą większą bądź mniejszą częścią powierzchni. Warstwa lita była pofałdowana, występowały na niej pęknięcia powierzchni oraz dziury o powierzchni niewypełnionej ziarnami.
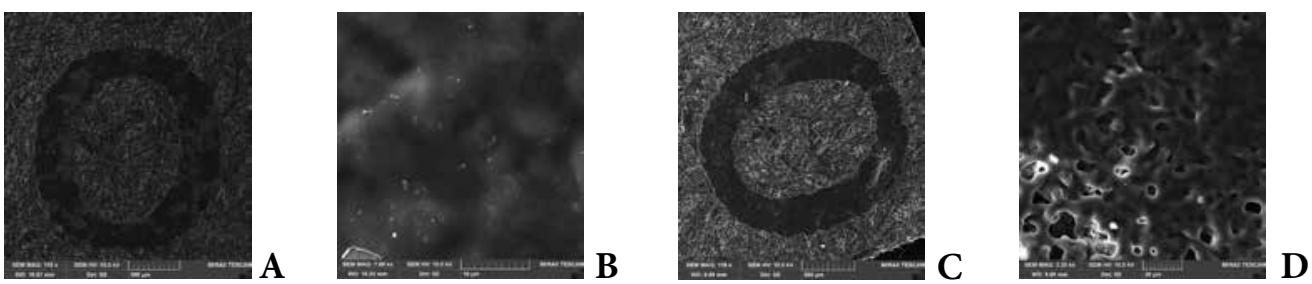

Zdj. 4. Obrazy SEM powierzchni litej tonerów dla wydruków wytworzonych z modeli: DCP-7055W - powiększenie 115× (A), powiększenie 7690× (B); DCP-7057E - powiększenie $119 \times(C)$, powiększenie $2200 \times(D)$.

W części ziarnistej tonerów cechą wyróżniającą dany model urządzenia był sposób rozmieszczenia ziaren oraz ich połączenie (mniejszą lub większą ich powierzchnią), wygląd skupisk, a także to, czy występowały one licznie w środku linii wydruku, czy po jej zewnętrznych stronach.

$\mathrm{Na}$ wydrukach $\mathrm{z}$ monochromatycznych drukarek laserowych $\mathrm{z}$ modeli: HL-2240 (zdj. 5 A), HL-2250DN (zdj. 5 B) oraz HL-7050 (zdj. 5 C) powierzchnia ziarnista składała się z pojedynczych ziaren bądź grup ziaren połączonych ze sobą większą lub mniejszą częścią powierzchni. Ziarna tworzyły łańcuchy, aglomeraty. Na wydrukach uzyskanych z dwóch pierwszych modeli obserwowano nieliczne pojedyncze ziarna występujące jedynie po zewnętrznych stronach linii wydruku. Z kolei na wydrukach uzyskanych $\mathrm{z}$ trzeciego modelu urządzenia pojedyncze ziarna, tak samo jak na wydrukach z poprzednich modeli, występowały po zewnętrznych stronach linii wydruku, ale było ich znacznie więcej.

$\mathrm{Na}$ wydrukach uzyskanych z modeli DCP-9042CDN (zdj. 5 D) oraz MFC-L-9570CDW (zdj. 5 E) należących do grupy kolorowych laserowych urządzeń wielofunkcyjnych obserwowano liczne pojedyncze ziarna występujące głównie po zewnętrznych stronach linii wydruku pojedynczego znaku. W przypadku wydruków 
z modelu DCP-9042CDN ziarna występowały zarówno pojedynczo, jak i grupami, najczęściej parami, połączone ze sobą większą lub mniejszą częścią powierzchni. Natomiast na wydrukach uzyskanych z modelu MFC-L9570CDW ziarna tworzyły aglomeraty bądź stopione skupiska.

W trzeciej grupie, którą były monochromatyczne laserowe urządzenia wielofunkcyjne, między badanymi wydrukami z dwóch modeli obserwowano wyraźne różnice. Na wydrukach z modelu DCP-7055W (zdj. 5 F) były widoczne bardzo liczne pojedyncze ziarna lub grupy ziaren występujące po zewnętrznych stronach linii wydruku, w modelu DCP-7057E (zdj. 5 G) natomiast zaobserwowano nieliczne pojedyncze ziarna lub całe ich grupy występujące jedynie po zewnętrznych stronach linii wydruku.
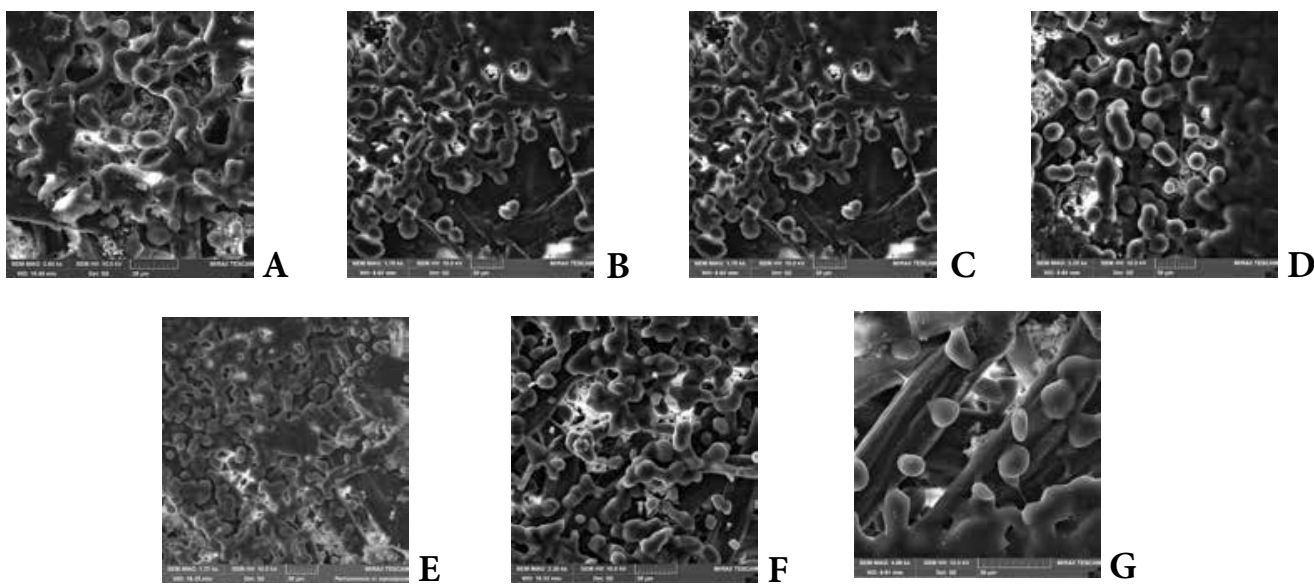

Zdj. 5. Obrazy SEM części ziarnistej tonera dla wydruków z modeli: HL-2240 - powiększenie 2640× (A), HL-2250DN - powiększenie 2540× (B), HL-7050 - powiększenie 1790× (C), DC-P-9042CDN - powiększenie 2250× (D), MFC-L9570CDW - powiększenie 1770× (E), DCP-7055W - powiększenie 2350× (F), DCP-7057E - powiększenie 4060× (G).

Analizę pojedynczych ziaren i ich struktury powierzchniowej przeprowadzono przy większych powiększeniach, tj. około 20 000-100 000×.

W przypadku wydruków uzyskanych z modeli należących do monochromatycznych drukarek laserowych stwierdzono różnice w kształcie pojedynczych ziaren. Dla modelu HL-2240 (zdj. 6 A i B) obserwowano ziarna o obłych wydłużonych kształtach. Na powierzchni ziaren występowały liczne niewielkie guzkowate struktury o kształcie kulistym i średnicy około $0,05 \mu \mathrm{m}$. Tuż pod powierzchnią ziaren były widoczne liczne struktury o nieregularnym kształcie, połączone ze sobą w łańcuchy lub tworzące aglomeraty, o średnicy około $0,02 \mu \mathrm{m}$. Średnica ziaren była zróżnicowana i wahała się w granicach 5-20 $\mu \mathrm{m}$.

Na wydruku z modelu HL-2250DN (zdj. 6 C i D) obserwowano ziarna o nieregularnych kształtach. Ich powierzchnia była pofałdowana, na niektórych były widoczne wyraźne załamania powierzchni. Nielicznie występowały tu również niewielkie nieregularne struktury o średnicy do około $0,1 \mu \mathrm{m}$. Tuż pod powierzchnią ziaren 
znajdowały się grupy struktur o nieregularnym kształcie, średnicy około $0,02 \mu \mathrm{m}$, połączone ze sobą w łańcuchy bądź tworzące aglomeraty, podobnie jak to obserwowano na wydrukach z modelu HL-2240. Średnica ziaren była zróżnicowana - od $4 \mu \mathrm{m}$ do $12 \mu \mathrm{m}$.

W przypadku wydruków z modelu HL-7050 (zdj. 6 E i F) obserwowano dwa rodzaje ziaren. Pierwszy miał kształt obły, prawie idealnie sferyczny. Ziarna charakteryzowały się gładką powierzchnią z nielicznymi strukturami o nieregularnym kształcie na ich powierzchni. Ich średnica wynosiła od $0,02 \mu \mathrm{m}$ do $0,1 \mu \mathrm{m}$. Tuż pod powierzchnią były widoczne liczne niewielkie struktury (o średnicy poniżej $0,01 \mu \mathrm{m}$ ) o nieregularnym kształcie, które tworzyły małe skupiska. Drugi rodzaj ziaren miał również kształt sferyczny. Ich powierzchnia była pofałdowana, zawierała liczne struktury guzkowate o średnicy około $0,05 \mu \mathrm{m}$, rozłożone po całej powierzchni ziarna, z wyjątkiem części, na której rozpościera się druga warstwa o gładkiej powierzchni. Kształtem przypominała łatę, była okrągła, lekko wydłużona, podobna do powierzchni piłeczki tenisowej. $\mathrm{Na}$ brzegach łaty obserwowano nieregularne struktury o ostrych krawędziach. Tuż pod jej powierzchnią znajdowały się słabo widoczne nieliczne struktury o nieregularnych kształtach i zróżnicowanych wielkościach. Średnice obu rodzajów ziaren są podobne i wynosiły około $12 \mu \mathrm{m}$.

$\mathrm{W}$ grupie kolorowych laserowych urządzeń wielofunkcyjnych wydruki z modelu DCP-9042CDN (zdj. 6 G i H) charakteryzowały się obecnością ziaren o obłych, lekko wydłużonych kształtach, niektóre miały kształt sferyczny. Powierzchnie tych ziaren były do siebie podobne. Występowały na nich liczne struktury o różnym kształcie i średnicy $0,05-0,1 \mu \mathrm{m}$. Tuż pod powierzchnią ziaren można było zauważyć liczne struktury o nieregularnym kształcie i różnej wielkości. Średnica ziaren była w niewielkim stopniu zróżnicowana i wynosiła od $6 \mu \mathrm{m}$ do $10 \mu \mathrm{m}$.

Na wydrukach uzyskanych z modelu MFC-L9570CDW (zdj. 6 I i J) obserwowano obecność ziaren tonera o sferycznych kształtach. Powierzchnia ziaren była morfologicznie podobna. Były na niej widoczne drobne struktury - guzki o średnicy 0,06 $\mu \mathrm{m}$ oraz nieregularne struktury o średnicy od 0,1 do $0,2 \mu \mathrm{m}$. Powierzchnia ziaren była pofałdowana, a ich średnica wynosiła od $5 \mu \mathrm{m}$ do $9 \mu \mathrm{m}$.

W ostatniej badanej grupie, w której były monochromatyczne laserowe urządzenia wielofunkcyjne, wydruki z modelu DCP-7055W (zdj. 6 K i L) charakteryzowały się obecnością ziaren w kształcie nieregularnych zwartych brył. Na powierzchniach ziaren występowały nieliczne rysy oraz nieregularne struktury o różnym kształcie i wielkości. W pozostałych miejscach powierzchnia ziaren była gładka. Tuż pod ich powierzchnią znajdowały się struktury o nieregularnym kształcie, połączone ze sobą w łańcuchy. Miały one średnicę od $0,02 \mu \mathrm{m}$ do $0,1 \mu \mathrm{m}$. Średnica ziaren była zróżnicowana i wynosiła $4-10 \mu \mathrm{m}$.

Z kolei na wydrukach z modelu DCP-7057E (zdj. 6 Ł i M) występowały ziarna o obłych, wydłużony kształtach. Powierzchnia ziaren morfologicznie była podobna, pofałdowana. Pod ich powierzchnią obserwowano liczne struktury o nieregularnym kształcie. Średnica ziaren wynosiła od $10 \mu \mathrm{m}$ do $12 \mu \mathrm{m}$. 

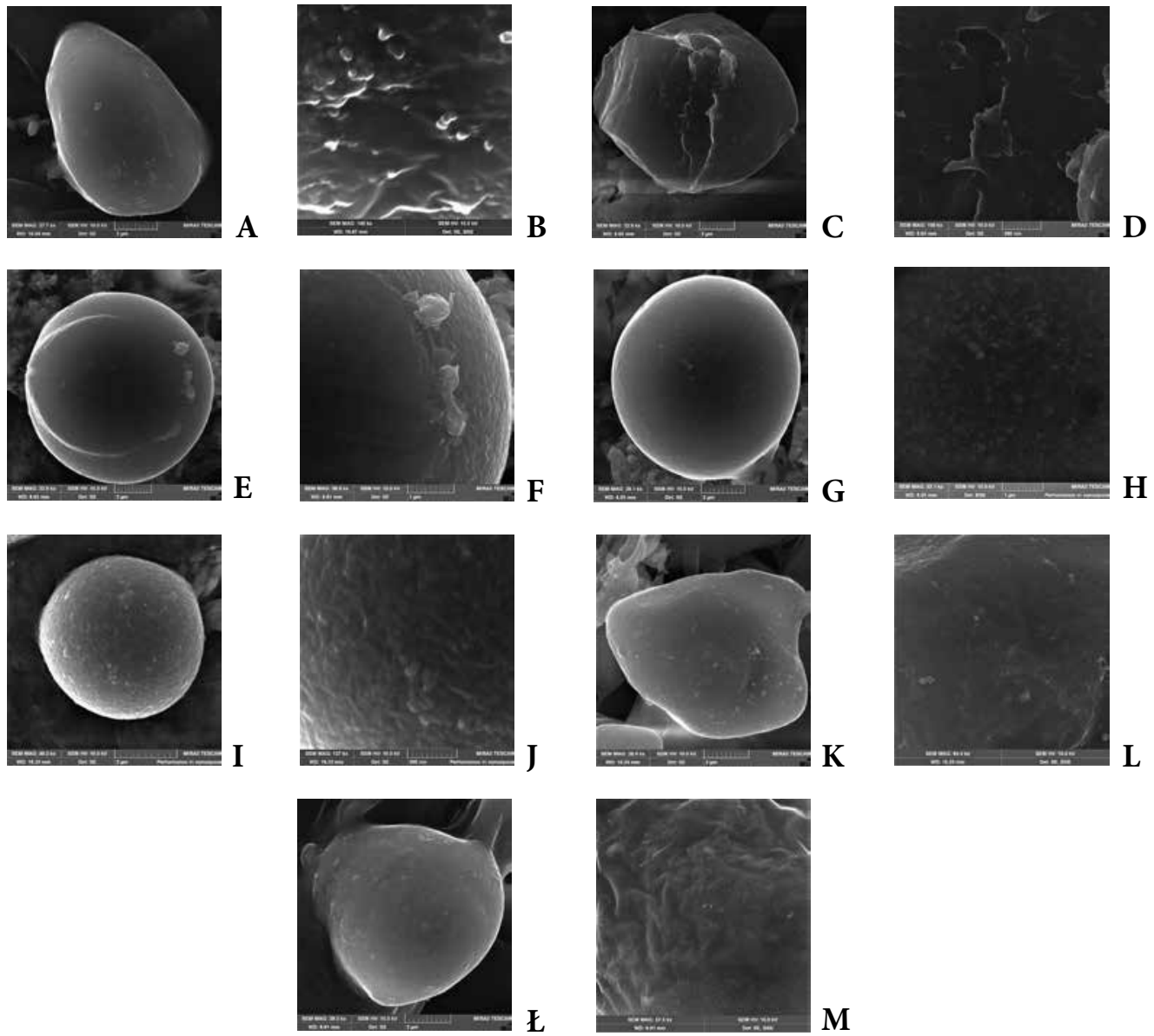

Zdj. 6. Obrazy SEM ziaren tonerów dla wydruków wytworzonych z modeli: HL-2240 powiększenie $27700 \times(\mathrm{A})$, powiększenie $148000 \times(\mathrm{B})$; HL-2250DN - powiększenie $22600 \times(\mathrm{C})$, powiększenie $27700 \times(\mathrm{D})$; HL-7050 - powiększenie $23600 \times(\mathrm{E})$, powiększenie $59700 \times(\mathrm{F})$; DCP-9042CDN - powiększenie $28100 \times(\mathrm{G})$, powiększenie $52100 \times(\mathrm{H})$; MFC-L9570CDW powiększenie $40200 \times$ (I), powiększenie $127000 \times$ (J); DCP-7055W - powiększenie $28300 \times(\mathrm{K})$, powiększenie 64 400× (L); DCP-7057E - powiększenie 29 300× (Ł), powiększenie $57500 \times(\mathrm{M})$.

\section{Laserowe urządzenia drukujące firmy Konica Minolta}

Na wydruku uzyskanym z kolorowej drukarki laserowej model Bizhub c35 (zdj. 7) warstwa tonera tworzyła dwie strefy o powierzchni litej oraz ziarnistej. Obszar powierzchni litej był przerywany niewielkimi i nielicznymi obszarami powierzchni ziarnistej, przyjmującej postać niewielkich łat. Powierzchnia lita była gładka, z delikatnymi zarysowaniami, niewielkimi i nielicznymi zrębami lub innymi „uszkodzeniami” struktury powierzchni. Przy powiększeniu około160× zaobserwowano na niej również nieliczne struktury o nieregularnych kształtach i średnicy do około $0,2 \mu \mathrm{m}$. W powiększeniu ponad $11500 \times$ uwidaczniało się, że powierzchnia strefy litej tonera była gładka 
oraz że znajdowały się na niej delikatne zarysowania, niewielkie i nieliczne zręby oraz inny rodzaj struktur pod względem kształtu czy ogólnego wyglądu na powierzchni litej.
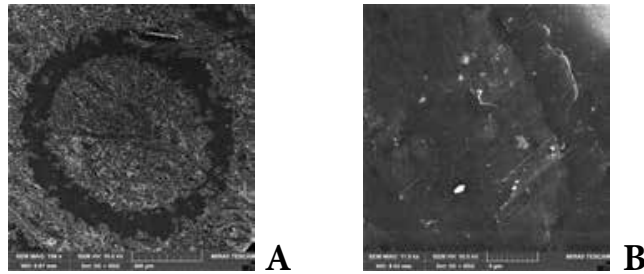

Zdj. 7. Obrazy SEM powierzchni litej tonerów dla wydruków wytworzonych z modelu Bizhub c35 - powiększenie 158× (A), powiększenie $11500 \times$ (B).

W przypadku wydruków uzyskanych z pięciu kolorowych laserowych urządzeń wielofunkcyjnych zaobserwowano istotne różnice $\mathrm{w}$ sposobie rozłożenia warstwy tonera już przy powiększeniu od $100 \times$ do $200 \times$. Na wydruku uzyskanym z modelu Bizhub c25 (zdj. 8 A i B) warstwa lita była przerywana licznymi obszarami powierzchni ziarnistej. Była ona gładka, pofałdowana, z widocznymi delikatnymi zarysowaniami oraz zagłębieniami. Na jej powierzchni stwierdzono również nieliczne struktury o nieregularnych kształtach i różnych średnicach - od 0,05 $\mu \mathrm{m}$ do $0,2 \mu \mathrm{m}$.

W modelu Bizhub 42 (zdj. 8 C i D) część lita tonera stanowiła przeważającą część powierzchni wydruku. Powierzchnia lita była gładka, występowały w niej liczne pęknięcia i dziury. Obserwowano na niej również nieliczne struktury o nieregularnych kształtach i średnicach do około $0,2 \mu \mathrm{m}$.

Wydruki z modelu Bizhub c224 (zdj. 8 E i F) dały obrazy warstwy litej, przerywanej dużymi obszarami powierzchni ziarnistej. Była ona pofałdowana, występowały w niej również nieliczne pęknięcia, dziury oraz zarysowania. Na powierzchni warstwy litej można było zaobserwować liczne struktury o nieregularnych kształtach i średnicy od 0,05 $\mu \mathrm{m}$ do $0,2 \mu \mathrm{m}$, tworzące skupiska lub występujące pojedynczo.

$\mathrm{Na}$ wydruku z modelu Bizhub c552 (zdj. 8 G i H) warstwa lita była przerywana licznymi obszarami powierzchni ziarnistej, które przeważały nad częścią litą. Powierzchnia lita była nierównomierna, można było w niej zaobserwować wiele pęknięć, zrębów oraz zagłębień. Brzegi zrębów były ostre i tworzyły duże obszary, których końce nie przylegały do pozostałej powierzchni tonera. Na powierzchni warstwy litej można było dostrzec również liczne struktury o nieregularnych kształtach i średnicach od $0,05 \mu \mathrm{m}$ do $0,5 \mu \mathrm{m}$.

W przypadku modelu Bizhub c754 (zdj. 8 I i J) na wydrukach było widać warstwę litą przerywaną licznymi, dużymi płatami powierzchni ziarnistej. Ta powierzchnia przeważała nad częścią litą, znacznie większą niż w modelu Bizhub c552. Powierzchnia lita była pofałdowana i w charakterystyczny sposób tworzyła okrągłe wybrzuszenia. Można było zobaczyć nieliczne pojedyncze struktury o nieregularnych kształtach i średnicach od $5 \mu \mathrm{m}$ do $6 \mu \mathrm{m}$ oraz drobne struktury o nieregularnych kształtach i średnicy poniżej $0,5 \mu \mathrm{m}$. 

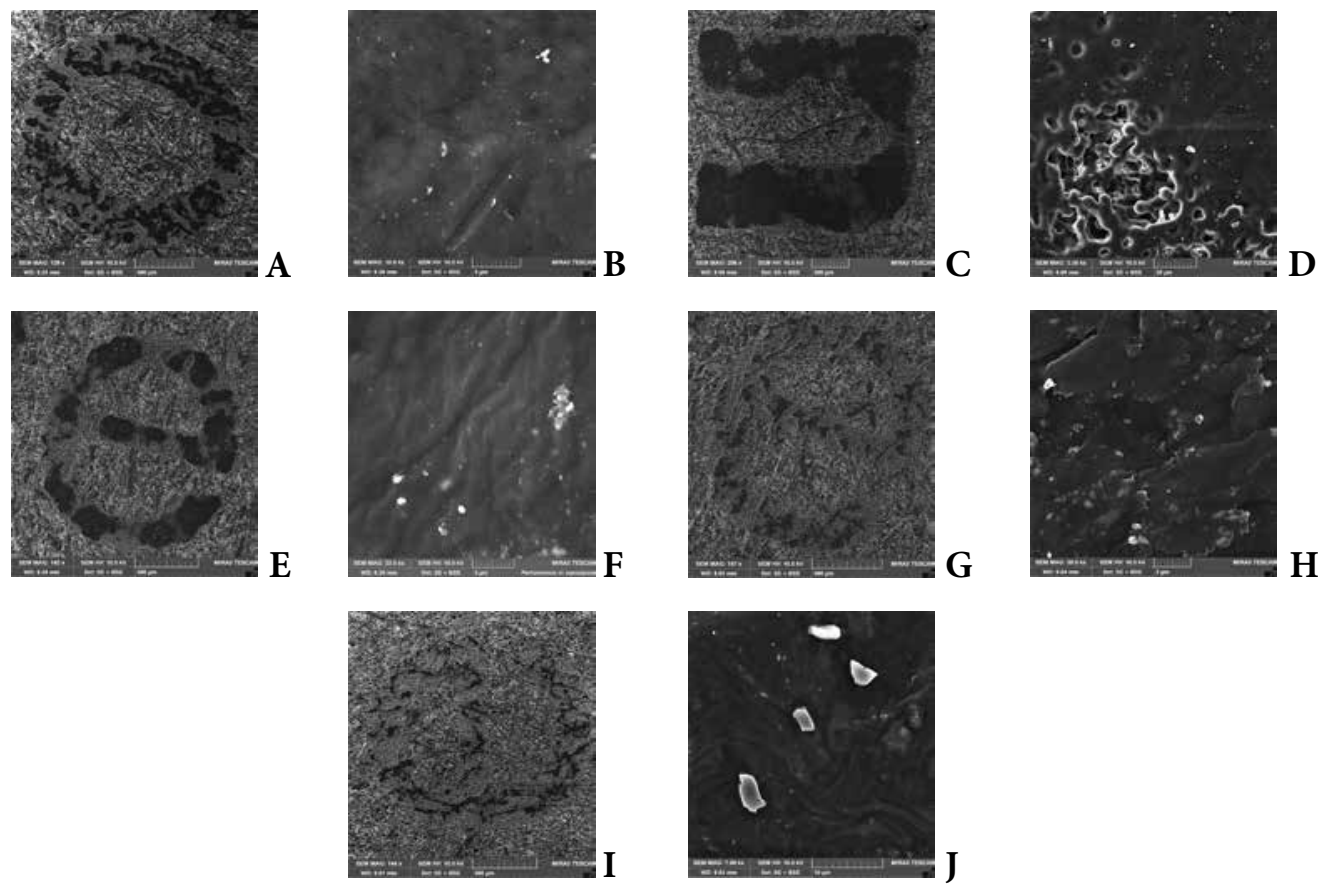

Zdj. 8. Obrazy SEM powierzchni litej tonerów dla wydruków wytworzonych z modeli Bizhub c25 - powiększenie 120× (A), powiększenie 19 800× (B); Bizhub 42 - powiększenie 206× (C), powiększenie 2380× (D); Bizhub c224 - powiększenie 142× (E), powiększenie $23000 \times(\mathrm{F})$; Bizhub c552 - powiększenie 157× (G), powiększenie 20 500× (H); Bizhub c754 - powiększenie $144 \times(\mathrm{I})$, powiększenie $7690 \times(\mathrm{J})$.

W grupie monochromatycznych laserowych urządzeń wielofunkcyjnych analizie poddano wydruki z trzech modeli urządzeń: Bizhub 283, Bizhub 501 oraz Bizhub 552. Na wszystkich wydrukach warstwa tonera tworzyła obszary powierzchni litej oraz ziarnistej. Zaobserwowano zmienność w rozkładzie powierzchni strefy ziarnistej w stosunku do powierzchni litej. Strefa lita występowała w postaci licznych obszarów łat o różnej wielkości na obszarze całej linii wydruku pojedynczego znaku.

W przypadku wydruków z modelu Bizhub 283 (zdj. 9 A i B) powierzchnia lita była pofałdowana, znajdowały się na niej rysy oraz zręby. Można było również zauważyć zarysy kształtów ziaren. Na powierzchni warstwy litej stwierdzono nieliczne struktury o nieregularnych kształtach i średnicy do $0,1 \mu \mathrm{m}$.

$\mathrm{Na}$ wydrukach uzyskanych z modelu Bizhub 501 (zdj. 9 C i D) powierzchnia lita była pofałdowana, występowały w niej liczne okrągłe dziury oraz nieliczne pęknięcia. Były widoczne zarysy kształtu ziaren. Na powierzchni oraz tuż pod powierzchnią części litej znajdowały się liczne struktury o średnicy około 0,05 $\mu \mathrm{m}$.

Natomiast na wydrukach uzyskanych z modelu Bizhub 552 (zdj. 9 E i F) powierzchnia lita była gładka, z nielicznymi zrębami, dziurami i pęknięciami. Na powierzchni warstwy litej gdzieniegdzie zaobserwowano struktury o nieregularnych kształtach i różnych średnicach poniżej $0,1 \mu \mathrm{m}$. 

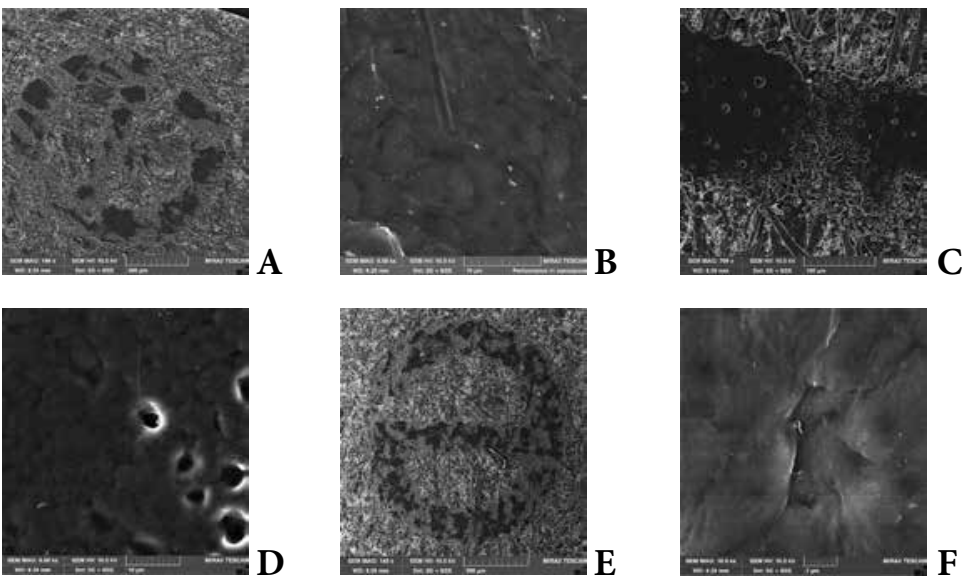

Zdj. 9. Obrazy SEM powierzchni strefy litej tonerów dla wydruków wytworzonych z modeli Bizhub 283 - powiększenie 140× (A), powiększenie 8580× (B); Bizhub 501 - powiększenie 799× (C), powiększenie $6080 \times(\mathrm{D})$; Bizhub 552 - powiększenie $145 \times(\mathrm{E})$, powiększenie $18600 \times(\mathrm{F})$.

$\mathrm{Na}$ wydrukach uzyskanych z kolorowej drukarki laserowej model Bizhub C35 (zdj.10 A) powierzchnia ziarnista była zróżnicowana. Można było zaobserwować ziarna wtopione w powierzchnię, tworzące łańcuchy lub wysepki o wyraźnie widocznych granicach ziaren. Nieliczne pojedyncze ziarna bądź grupy ziaren występowały w środkowej części oraz po zewnętrznych stronach linii wydruku.

W grupie wydruków uzyskanych z kolorowych urządzeń wielofunkcyjnych w modelach Bizhub c25 (zdj. 10 B), Bizhub c224 (zdj. 10 D), Bizhub c552 (zdj. 10 E) oraz Bizhub c754 (zdj. 10 F) powierzchnia ziarnista była również zróżnicowana. Ziarna były wtopione w powierzchnię i tworzyły łańcuchy bądź wysepki o wyraźnie widocznych zarysach kształtu ziaren. Liczne pojedyncze ziarna lub grupy ziaren występowały w środkowej części oraz po zewnętrznych stronach linii wydruku. Jedynie na wydrukach uzyskanych z modelu Bizhub 42 (zdj. 10 C) powierzchnia ziarnista występowała głównie po zewnętrznych stronach linii wydruku. W niektórych miejscach wchodziła głęboko w linię wydruku bądź przecinała ją na wylot. Liczne pojedyncze ziarna lub grupy ziaren połączonych ze sobą w łańcuszki występowały gównie po zewnętrznych stronach linii wydruku.

Wydruki z monochromatycznych urządzeń wielofunkcyjnych modeli: Bizhub 283 (zdj. 10 G), Bizhub 501 (zdj. 10 H) oraz Bizhub 552 (zdj. 10 I) charakteryzowały się obecnością aglomeratów w postaci łańcuszków i wysepek o wyraźnie widocznych zarysach ziaren, które były ze sobą połączone. Występowały również ziarna wtopione w powierzchnię, głównie na brzegach powierzchni litej przechodzącej w ziarnistą. Liczne pojedyncze ziarna lub grupy ziaren znajdowały się w środkowej części oraz po zewnętrznych stronach linii wydruku. W przypadku tych urządzeń trudno jednak było zaobserwować istotne różnice między poszczególnymi modelami. 

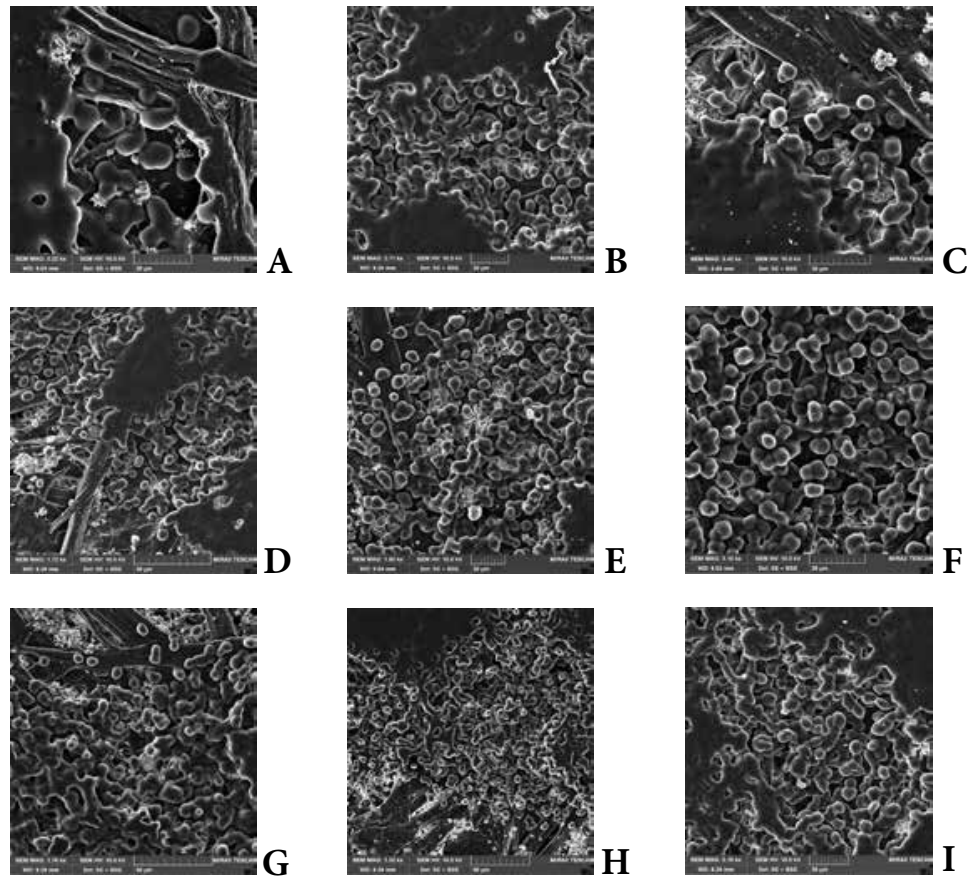

Zdj. 10. Obrazy SEM części ziarnistej tonera dla wydruków z modeli Bizhub c35 - powiększenie 3220× (A); Bizhub c25 - powiększenie 2110× (B); Bizhub 42- powiększenie 3420× (C); Bizhub c224 - powiększenie 1720× (D); Bizhub c552 - powiększenie 1930× (E); Bizhub c754 - powiększenie $3100 \times(F)$; Bizhub 283 - powiększenie $1760 \times(\mathrm{G})$; Bizhub 501 - powiększenie $1320 \times(\mathrm{H})$; Bizhub 552 - powiększenie $2180 \times(\mathrm{I})$.

Analizę pojedynczych ziaren i ich struktury powierzchniowej przeprowadzono przy powiększeniach ponad $25000 \times$.

Z grupy kolorowych drukarek laserowych przeanalizowano wydruki uzyskane tylko z jednego modelu - Bizhub c35 (zdj. 11 A). Na wydrukach ziarna miały kształt obły, niektóre były lekko wydłużone, inne przypominały balonik ściągnięty w jednym końcu. Powierzchnia ziaren była grudkowata, lekko pofałdowana, z nielicznymi zagłębieniami oraz pojedynczymi przypowierzchniowymi pęknięciami. Wokół brzegów pęknięć były widoczne skupiska guzkowatych struktur mających średnicę 0,05 $\mu \mathrm{m}$. Tego typu struktury pokrywały całą powierzchnię ziaren. Ponadto można było zaobserwować nieliczne niewielkie struktury o nieregularnych kształtach i średnicy od $0,05 \mu \mathrm{m}$ do $0,2 \mu \mathrm{m}$. Średnicę ziaren oszacowano na 6-12 $\mu \mathrm{m}$.

Wydruki uzyskane z pięciu modeli należących do grupy kolorowych urządzeń wielofunkcyjnych wykazały zróżnicowanie ziaren tonera pod względem strukturalnym. Toner na wydrukach uzyskanych z modelu Bizhub c25 (zdj. 11 B) charakteryzował się obecnością ziaren o kształtach obłych, jedne były bardziej sferyczne, inne lekko wydłużone. Powierzchnia ziaren była pofałdowana na brzegach, stwierdzono też nieliczne zagłębienia. Na powierzchni ziaren licznie występowały niewielkie struktury zróżnicowane pod względem kształtu i wielkości - od 0,05 $\mu \mathrm{m}$ do $0,1 \mu \mathrm{m}$. 
Tworzyły one małe skupiska lub występowały pojedynczo. Średnica ziaren była szacowana na 5-10 $\mu \mathrm{m}$.

$\mathrm{Na}$ wydrukach uzyskanych z modelu Bizhub 42 (zdj. $11 \mathrm{C}$ ) ziarna tonera miały kształt obły, niektóre sferyczny, a jeszcze inne - nieregularny. Powierzchnia ziaren była lekko pofałdowana $z$ nielicznymi zagłębieniami. Na powierzchni ziaren stwierdzono występowanie licznych niewielkich struktur guzkowatych o zróżnicowanym kształcie - od bardziej sferycznych do nieregularnych, o ostrych krawędziach i średnicy od $0,05 \mu \mathrm{m}$ do $0,2 \mu \mathrm{m}$. Tuż pod powierzchnią ziaren były widoczne także różne nieregularne struktury. Wielkość ziaren wynosiła od $5 \mu \mathrm{m}$ do $8 \mu \mathrm{m}$.

Na wydrukach uzyskanych z modelu Bizhub c224 (zdj. 11 D) ziarna były obłe, podobnie jak w przypadku wydruków uzyskanych z modeli opisanych wcześniej. Niektóre przypominały kule, inne były bardziej wydłużone. Powierzchnia ziaren była pofałdowana w charakterystyczny sposób. Fałdy tworzyły zaokrąglone faliste wybrzuszenia i miały tendencję do układania się wokół pojedynczego ziarna. Na powierzchni ziaren występowały również nieliczne zagłębienia oraz pojedyncze przypowierzchniowe pęknięcia. Dno pęknięć było gładkie. Całą powierzchnię ziaren gęsto pokrywały niewielkie guzkowate struktury średnicy około $0,05 \mu \mathrm{m}$, tworzące skupiska wokół brzegów pęknięć, oraz nieliczne struktury o nieregularnym kształcie i średnicy około $0,2 \mu \mathrm{m}$. Wielkość ziaren wynosiła od $5 \mu \mathrm{m}$ do $8 \mu \mathrm{m}$.

Toner na wydrukach uzyskanych z modelu Bizhub c552 (zdj. $11 \mathrm{E}$ ) zawierał ziarna o kształtach regularnych. Niektóre z nich miały kształt sferyczny. Powierzchnia ziaren była lekko pofałdowana z pojedynczymi wgłębieniami, które wyglądały jak wkłucie igły, oraz nielicznymi pęknięciami. Gęsto ją pokrywały niewielkie guzkowate struktury o średnicy około 0,05 $\mu \mathrm{m}$, tworzące skupiska wokół brzegów pęknięć. Dno pęknięć było gładkie. Średnicę ziaren oszacowano na $5-9 \mu \mathrm{m}$.

Na wydrukach uzyskanych z modelu Bizhub c754 (zdj. 11 F) kształty ziaren były nieregularne. Ich powierzchnia była miejscami gładka, pofałdowana, z pojedynczymi wgłębieniami, zrębami oraz przypowierzchniowymi pęknięciami. Były widoczne również nieliczne pojedyncze struktury o średnicy około $0,4 \mu \mathrm{m}$ lub ich skupiska. Na niektórych ziarnach można było zobaczyć wiele małych guzkowatych struktur o średnicy około $0,05 \mu \mathrm{m}$. Ziarna miały około $9 \mu \mathrm{m}$.

W grupie monochromatycznych laserowych urządzeń wielofunkcyjnych stwierdzono zróżnicowanie kształtu i struktury ziaren w zależności od wybranego modelu urządzenia. Na wydrukach uzyskanych z modelu Bizhub 283 (zdj. 11 G) ziarna miały kształt obły. Niektóre przypominały kule, kształt innych był nieregularny. Powierzchnia ziaren była gładka, lekko pofałdowana, z zagłębieniami. Na powierzchni ziaren, głównie $\mathrm{w}$ zagłębieniach, licznie występowały niewielkie skupiska struktur o zróżnicowanym kształcie - od bardziej sferycznych do nieregularnych o ostrych krawędziach i średnicy około $0,05 \mu \mathrm{m}$. Można było dostrzec również struktury występujące tuż pod powierzchnią ziaren. Średnica ziaren wynosiła 5-10 $\mu \mathrm{m}$.

$\mathrm{Na}$ wydrukach uzyskanych z modelu Bizhub 501 (zdj. $11 \mathrm{H}$ ) ziarna miały kształty nieregularne. Ich powierzchnia była pofałdowana, występowały na niej zagłębienia oraz pojedyncze przypowierzchniowe pęknięcia. Wokół brzegów pęknięć znajdowały się 
niewielkie guzkowate struktury o średnicy około 0,05 $\mu \mathrm{m}$, które tworzyły skupiska. Dno pęknięć było gładkie. Na powierzchni ziaren oraz tuż pod ich powierzchnią były widoczne liczne struktury o różnych kształtach i średnicach powyżej 0,05 $\mu \mathrm{m}$. Średnica ziaren była szacowana na około $9 \mu \mathrm{m}$.

Na wydrukach uzyskanych z modelu Bizhub 552 (zdj. 11 I) ziarna miały kształty nieregularne. Ich powierzchnia była pofałdowana, występowały zagłębienia oraz liczne pęknięcia. Na całej powierzchni ziaren można było zobaczyć guzkowate struktury o średnicy około 0,05 $\mu \mathrm{m}$. Średnica ziaren wynosiła od $5 \mu \mathrm{m}$ do $10 \mu \mathrm{m}$.
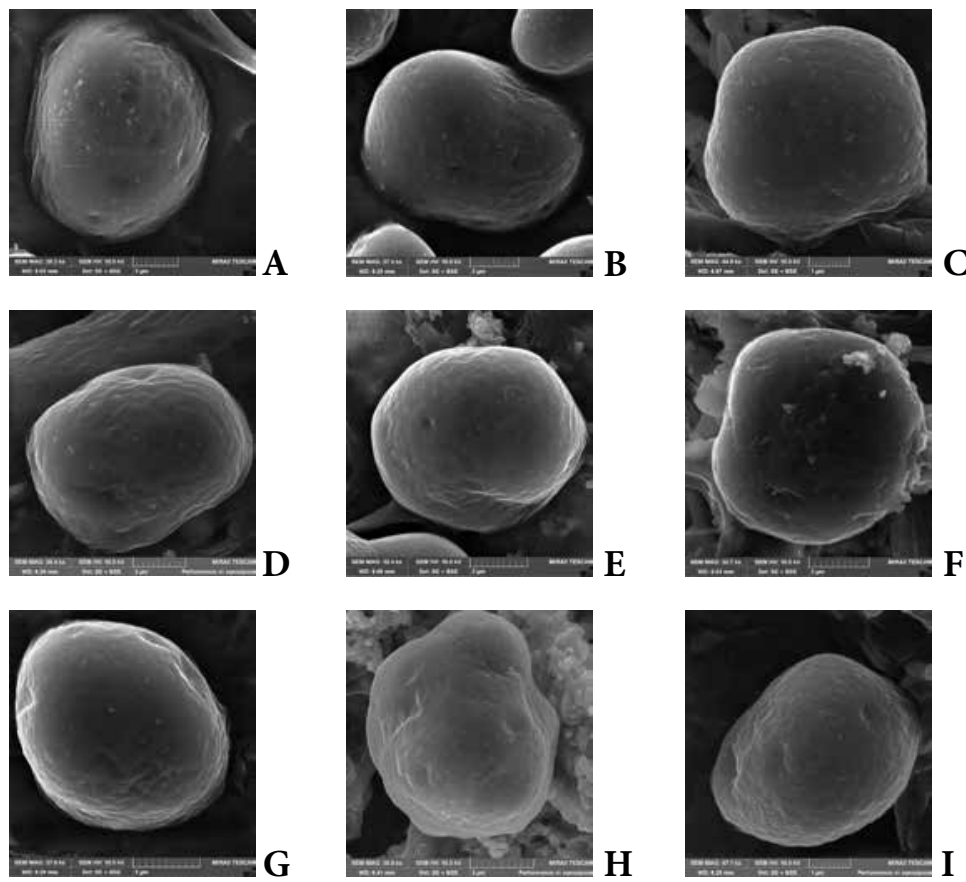

Zdj. 11. Obrazy SEM ziaren tonerów dla wydruków wytworzonych z modeli: Bizhub c35 powiększenie 25 200× (A); Bizhub c25 - powiększenie 27 400× (B); Bizhub 42- powiększenie 44 900× (C); Bizhub c224 - powiększenie 29 400× (D); Bizhub c552 - powiększenie 32 400× (E); Bizhub c754 - powiększenie 33 700× (F); Bizhub 283 - powiększenie $37600 \times(\mathrm{G})$; Bizhub 501 powiększenie $35800 \times(\mathrm{H})$; Bizhub 552 - powiększenie 47 100× (I).

\section{Zamienniki}

W dalszej części artykułu zostały przedstawione wyniki badań przeprowadzonych na wydrukach uzyskanych $\mathrm{z}$ różnych urządzeń drukujących $\mathrm{z}$ wykorzystaniem tonerów zastępczych, tzw. zamienników.

\section{Laserowe urządzenia drukujace firmy Brother}

Po analizie wydruków uzyskanych z laserowych urządzeń drukujących Brother stwierdzono, że warstwę tonera tworzą zarówno powierzchnia lita, jak i ziarnista. Różnica 
polega na stosunku jednej warstwy do drugiej i formie ich rozmieszczenia w obszarze danego znaku, w zależności od typu urządzenia.

Ocenie poddano wydruki $z$ dwóch monochromatycznych drukarek laserowych. $\mathrm{Na}$ wydruku uzyskanym z modelu HL-2150N (zdj. 12 A i B) obszar powierzchni litej był przerywany dużymi obszarami mającymi postać ziarnistą. Powierzchni litej było zdecydowanie mniej niż ziarnistej. Była ona pofałdowana, zawierała liczne załamania, zagłębienia, pęknięcia i dziury. Można było zaobserwować także pojedyncze struktury o nieregularnych kształtach i różnych wielkościach. Stwierdzono również obszary z zarysami ziaren, głównie na granicy przejścia powierzchni litej w ziarnistą.

Natomiast na wydrukach uzyskanych z modelu HL-2250DN (zdj. 12 C i D) obszar powierzchni litej przeważał nad ziarnistą. Część ziarnista miała postać nielicznych małych obszarów rozmieszczonych chaotycznie na powierzchni pojedynczego znaku. Powierzchnia lita była pofałdowana, zawierała wiele zagłębień i dziur. Widoczne na niej były także pojedyncze struktury o nieregularnych kształtach i różnych wielkościach. Podobnie jak w modelu HL-2150N tutaj również występowały obszary z zarysami ziaren, głównie na granicy przejścia powierzchni litej w ziarnistą.

$\mathrm{Na}$ wydrukach uzyskanych z modelu DCP9010CN (zdj. 12 E i F) należącego do grupy kolorowych laserowych urządzeń wielofunkcyjnych przeważał obszar powierzchni litej, choć przypominał on raczej powierzchnię ziarnistą. Znajdowały się tu wyraźne zarysy ziaren wtopionych w powierzchnię i ściśle ze sobą połączonych, tworzących zwartą warstwę tonera. Część ziarnista o typowej strukturze występowała w postaci nielicznych małych obszarów, głównie na brzegach linii wydruku. Na powierzchni litej tonera były widoczne pojedyncze struktury o nieregularnych kształtach i różnych wielkościach.
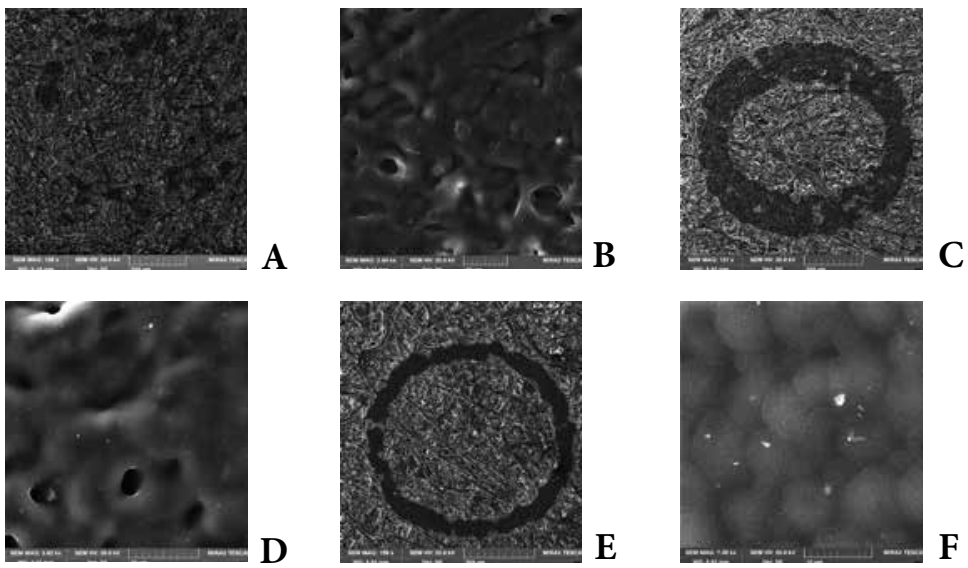

Zdj. 12. Obrazy SEM powierzchni litej tonerów dla wydruków wytworzonych z modeli: HL-2150N - powiększenie 128× (A), powiększenie 2440× (B); HL-2250DN - powiększenie $131 \times(C)$, powiększenie 3920× (D); DCP9010CN - powiększenie 159× (E), powiększenie $7850 \times(\mathrm{F})$. 
W przypadku wydruków $\mathrm{z}$ monochromatycznych drukarek laserowych $\mathrm{z}$ modeli: HL-2150N (zdj. 13 A) oraz HL-2250DN (zdj. 13 B) powierzchnia ziarnista składała się z pojedynczych ziaren lub grup ziaren połączonych ze sobą większą lub mniejszą częścią powierzchni. Ziarna tworzyły krótsze bądź dłuższe łańcuchy, aglomeraty. $\mathrm{Na}$ wydrukach uzyskanych z modelu HL-2150N pojedyncze ziarna występowały bardzo licznie w środkowej części oraz po zewnętrznych stronach linii wydruku. Natomiast na wydrukach $\mathrm{z}$ drugiego modelu obserwowano nieliczne pojedyncze ziarna występujące jedynie po zewnętrznych stronach linii wydruku.

Na wydrukach z modelu DCP9010CN (zdj. 13 C) należącego do grupy kolorowych laserowych urządzeń wielofunkcyjnych można było zauważyć liczne pojedyncze ziarna występujące głównie po zewnętrznych stronach linii wydruku badanego znaku. Były one rozmieszczone pojedynczo lub parami i połączone ze sobą większą lub mniejszą częścią powierzchni.
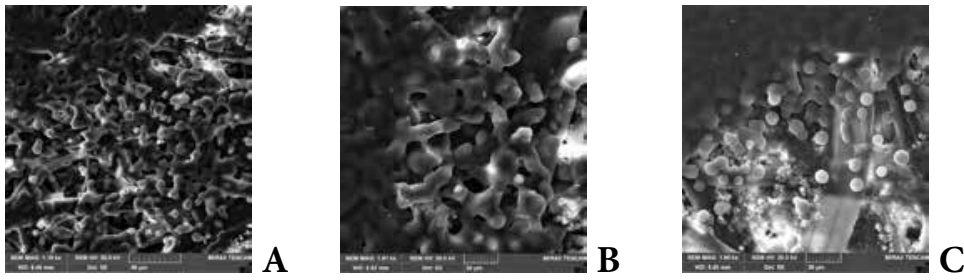

Zdj. 13. Obrazy SEM części ziarnistej tonera dla wydruków z modeli: HL-2150N - powiększenie 1160× (A); HL-2250DN - powiększenie 1910× (B); DCP9010CN - powiększenie 1950× (C).

Analizę pojedynczych ziaren i ich struktury powierzchniowej przeprowadzono przy powiększeniach - od około $20000 \times$ do około $100000 \times$. W przypadku wydruków uzyskanych z modeli należących do monochromatycznych drukarek laserowych obserwowano różnice w kształcie pojedynczych ziaren. W przypadku modelu HL-2150N (zdj. 14 A i B) ziarna miały kształty nieregularne. Powierzchnia ziaren była pofałdowana, występowały na niej nieliczne, niewielkie skupiska guzkowatych struktur o kształcie kulistym, średnicy około $0,05 \mu \mathrm{m}$, a także inne drobne struktury o kształtach nieregularnych. Średnica ziaren była zróżnicowana i wynosiła od $5 \mu \mathrm{m}$ do $10 \mu \mathrm{m}$.

Na wydruku z modelu HL-2250DN (zdj. 14 C i D) ziarna miały kształt obły, lekko wydłużony. Na powierzchni ziaren stwierdzono pofałdowania na brzegach. Występowały na niej nieliczne nieregularne struktury wyglądające jak kryształki o różnych średnicach - do około $1 \mu \mathrm{m}$. Znajdowały się tu również nieliczne niewielkie skupiska guzkowatych struktur mających kulisty kształt, o średnicy około 0,05 $\mu \mathrm{m}$. Tuż pod powierzchnią ziaren występowały grupy struktur o nieregularnych kształtach i różnych średnicach. Wielkość ziaren była szacowana na około $10 \mu \mathrm{m}$.

Tonery na wydrukach $\mathrm{z}$ modelu DCP9010CN (zdj. 14 E i F), zakwalifikowanego do grupy kolorowych laserowych urządzeń wielofunkcyjnych, charakteryzowały się obecnością ziaren o obłych kształtach. Niektóre ziarna przypominały kule. Powierzchnia ziaren była podobna. Można było stwierdzić również pojedyncze 
wgłębienia. $\mathrm{Na}$ ich powierzchni licznie występowały pojedyncze guzkowate struktury o kulistym kształcie i średnicy od $0,05 \mu \mathrm{m}$ do $0,1 \mu \mathrm{m}$ lub ich skupiska. Tuż pod powierzchnią ziaren występowały liczne struktury o nieregularnym kształcie i różnej wielkości. Średnica ziaren była w niewielkim stopniu zróżnicowana i wahała się od $4 \mu \mathrm{m}$ do $9 \mu \mathrm{m}$.
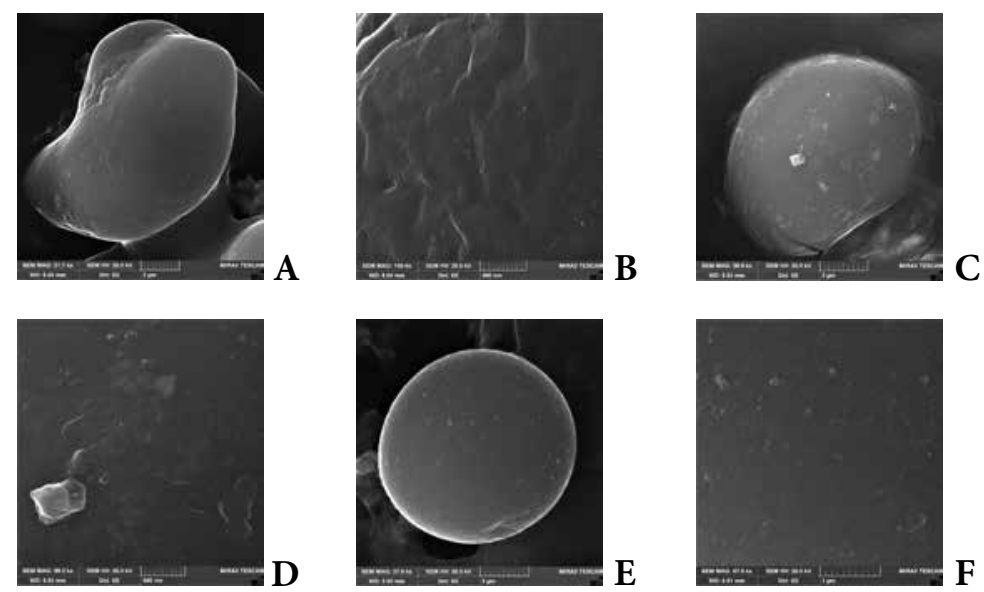

Zdj. 14. Obrazy SEM ziaren tonerów dla wydruków wytworzonych z modeli: HL-2150N - powiększenie 21 700× (A), powiększenie $105000 \times$ (B); HL-2250DN - powiększenie $26900 \times$ (C), powiększenie $99200 \times(\mathrm{D})$; DCP9010CN - powiększenie $27600 \times(\mathrm{E})$, powiększenie $67800 \times(\mathrm{F})$.

\section{Laserowe urządzenia drukujące firmy Konica Minolta}

W przypadku wydruków uzyskanych z laserowych urządzeń drukujących Konica Minolta analiza powierzchni tonera wykazała, że na wszystkich wydrukach warstwę tonera tworzyły powierzchnie lita oraz ziarnista. W zależności od typu urządzenia odmienny był natomiast stosunek jednej warstwy do drugiej i forma ich rozmieszczenia w obszarze danego znaku.

Na wydrukach uzyskanych z modelu Bizhub c35 (zdj. 15 A i B) należącego do grupy kolorowych drukarek laserowych warstwa tonera tworzyła dwie strefy o powierzchni litej oraz ziarnistej. Obszar powierzchni litej był przerywany licznymi obszarami powierzchni ziarnistej o różnych wielkościach i kształtach. Powierzchnia lita była gładka, pofałdowana, z nielicznymi dziurami oraz licznymi zagłębieniami. Te zagłębienia były wynikiem zarysu obecnych tam sieci ziaren. Powierzchnia ziarnista występowała w postaci łat.

Na wydruku uzyskanym z modelu Bizhub c25 (zdj.15 C i D), należącego do grupy kolorowych laserowych urządzeń wielofunkcyjnych, warstwa lita była przerywana licznymi obszarami powierzchni ziarnistej. Powierzchnia ziarnista wyglądała jak cienkie linie, które prostopadle przecinały powierzchnię litą pojedynczego znaku. Gdzieniegdzie były to niewielkie obszary o różnych kształtach i wielkościach. 
Powierzchnia lita była pofałdowana, znajdowały się na niej zarysowania, zagłębienia oraz dziury, dało się zauważyć także zarysy ziaren. Na powierzchni warstwy litej były widoczne również nieliczne struktury o nieregularnych kształtach i różnych średnicach do około $0,5 \mu \mathrm{m}$.
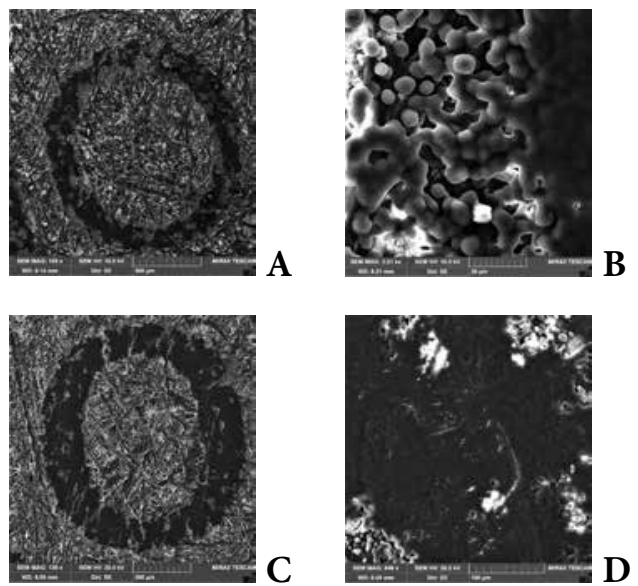

Zdj. 15. Obrazy SEM powierzchni litej tonerów dla wydruków wytworzonych z modeli Bizhub c35 - powiększenie 153× (A), powiększenie 3210× (B); Bizhub c25 - powiększenie 130× (C), powiększenie $846 \times(\mathrm{D})$.

Analiza części ziarnistej tonerów nie wykazała istotnych różnic w obu badanych modelach. Można było zaobserwować na nich ziarna wtopione w powierzchnię, które tworzyły łańcuchy lub wysepki o wyraźnie widocznych granicach ziaren. Liczne pojedyncze ziarna lub ich grupy znajdowały się w środkowej części oraz po zewnętrznych stronach linii wydruku (zdj. 16).
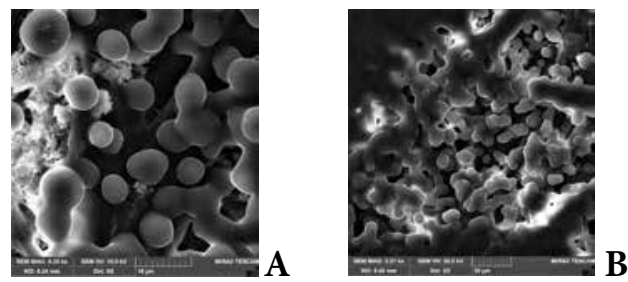

Zdj. 16. Obrazy SEM części ziarnistej tonera dla wydruków z modeli: Bizhub c35 - powiększenie $6250 \times(A)$; Bizhub c25 - powiększenie 2210× (B).

Analizę pojedynczych ziaren i ich struktury powierzchniowej przeprowadzono przy powiększeniach do ponad $120000 \times$. W obu modelach ziarna przyjmowały kształty nieregularne, najczęściej obłe, niektóre były lekko wydłużone lub bardziej sferyczne. Powierzchnia ziaren była lekko pofałdowana, występowały na niej nieliczne zagłębienia oraz pojedyncze dziury. 
W przypadku wydruków uzyskanych z modelu Bizhub c35 (zdj. 17 A i B) tuż pod powierzchnią ziaren obserwowano pojedyncze struktury o nieregularnych kształtach i różnych średnicach do około $0,2 \mu \mathrm{m}$. Średnica ziaren dla modelu Bizhub c35 była szacowana na 4-9 $\mu \mathrm{m}$. Natomiast na powierzchni ziaren z wydruków uzyskanych z modelu Bizhub c25 (zdj. 17 C i D) były widoczne liczne skupiska guzkowatych struktur mających średnicę poniżej $0,05 \mu \mathrm{m}$ oraz pojedyncze struktury o nieregularnych kształtach i średnicach również poniżej $0,05 \mu \mathrm{m}$. Średnica ziaren dla tego modelu wynosiła 5-10 $\mu \mathrm{m}$.
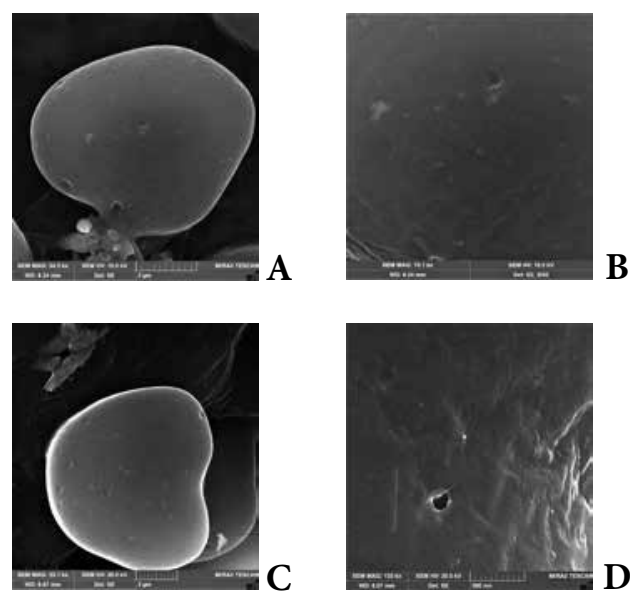

Zdj. 17. Obrazy SEM ziaren tonerów dla wydruków wytworzonych z modeli: Bizhub c35 powiększenie 34 300× (A), powiększenie 73 100× (B); Bizhub c25 - powiększenie $23100 \times(C)$, powiększenie $123000 \times(\mathrm{D})$.

\section{Porównanie oryginalnego tonera i jego zamiennika}

Analizę porównawczą przeprowadzono na wydrukach uzyskanych z trzech typów urządzeń drukujących: monochromatycznej drukarki laserowej Brother HL-2250DN, kolorowej drukarki laserowej Konica Minolta Bizhub c35 oraz kolorowego laserowego urządzenia wielofunkcyjnego Konica Minolta Bizhub c25. Do badań wykorzystano oryginalne tonery oraz ich zamienniki pochodzące od jednego dystrybutora.

Wydruki z monochromatycznej drukarki laserowej Brother HL-2250DN wykonane $\mathrm{z}$ wykorzystaniem oryginalnego tonera oraz zamiennika różniły się przede wszystkim kształtem i liczebnością ziaren. Powierzchnia ziaren w przypadku zamienników była pokryta nielicznymi drobinami struktur o nieregularnych kształtach i jasnym kontraście mikroskopowym. Wyraźnie było widać, że ziarna były wtopione w powierzchnię tonera lub papieru. $\mathrm{Na}$ wydrukach sporządzonych zamiennikami tonera pojedyncze ziarna występowały nielicznie, raczej tworzyły aglomeraty i można je było zobaczyć jedynie jako uwypuklenie na powierzchni papieru lub tonera. 
$\mathrm{Na}$ wydrukach uzyskanych z kolorowej drukarki laserowej Konica Minolta Bizhub c35 różnice między wydrukami sporządzonymi przy użyciu oryginalnego tonera a zamiennika były widoczne w obrazie powierzchni litej oraz kształcie i liczebności ziaren. W oryginalnym tonerze na powierzchni litej występowały liczne pęknięcia. W zamienniku natomiast powierzchnia lita była pofałdowana, wyraźnie były widoczne również zarysy kształtu ziaren. Ziarna występowały liczniej po zewnętrznych stronach linii nadruku niż na wydrukach wykonanych z zastosowaniem oryginalnego tonera. Oryginalny toner charakteryzował się natomiast cechą, której nie obserwowano w zamiennikach, czyli kształtem ziaren, które przypominały lekko wydłużony balonik, zwężony na jednym końcu.

W przypadku wydruków uzyskanych z kolorowego laserowego urządzenia wielofunkcyjnego Konica Minolta Bizhub c25 można było stwierdzić, że różnice między oryginalnym tonerem a zamiennikiem dotyczą gównie kształtu i liczebności ziaren. $\mathrm{Na}$ wydrukach wykonanych zarówno oryginalnym tonerem, jak i zamiennikiem cechy powierzchni litej były podobne. Różniły się natomiast liczebnością ziaren, których więcej było na wydrukach wykonanych oryginalnym tonerem. Tutaj było także więcej ziaren, które miały kształt sferyczny, niż to obserwowano na wydrukach wykonanych zamiennikami.

W tabelach 3 i 4 przedstawiono wszystkie cechy analizowanych oryginalnych tonerów oraz zamienników naniesionych na papier za pomocą urządzeń drukujących Brother i Konica Minolta. Tabele podzielono na dwie części. W pierwszej zawarto cechy powierzchni litej, w której wyszczególniono własności powierzchni (topografia powierzchni), rodzaj i wielkość struktur występujących w tonerach, w drugiej zaś cechy powierzchni ziarnistej, z opisem topografii powierzchni ziaren, ich kształtu, rozmiaru i struktur występujących na ich powierzchniach. 


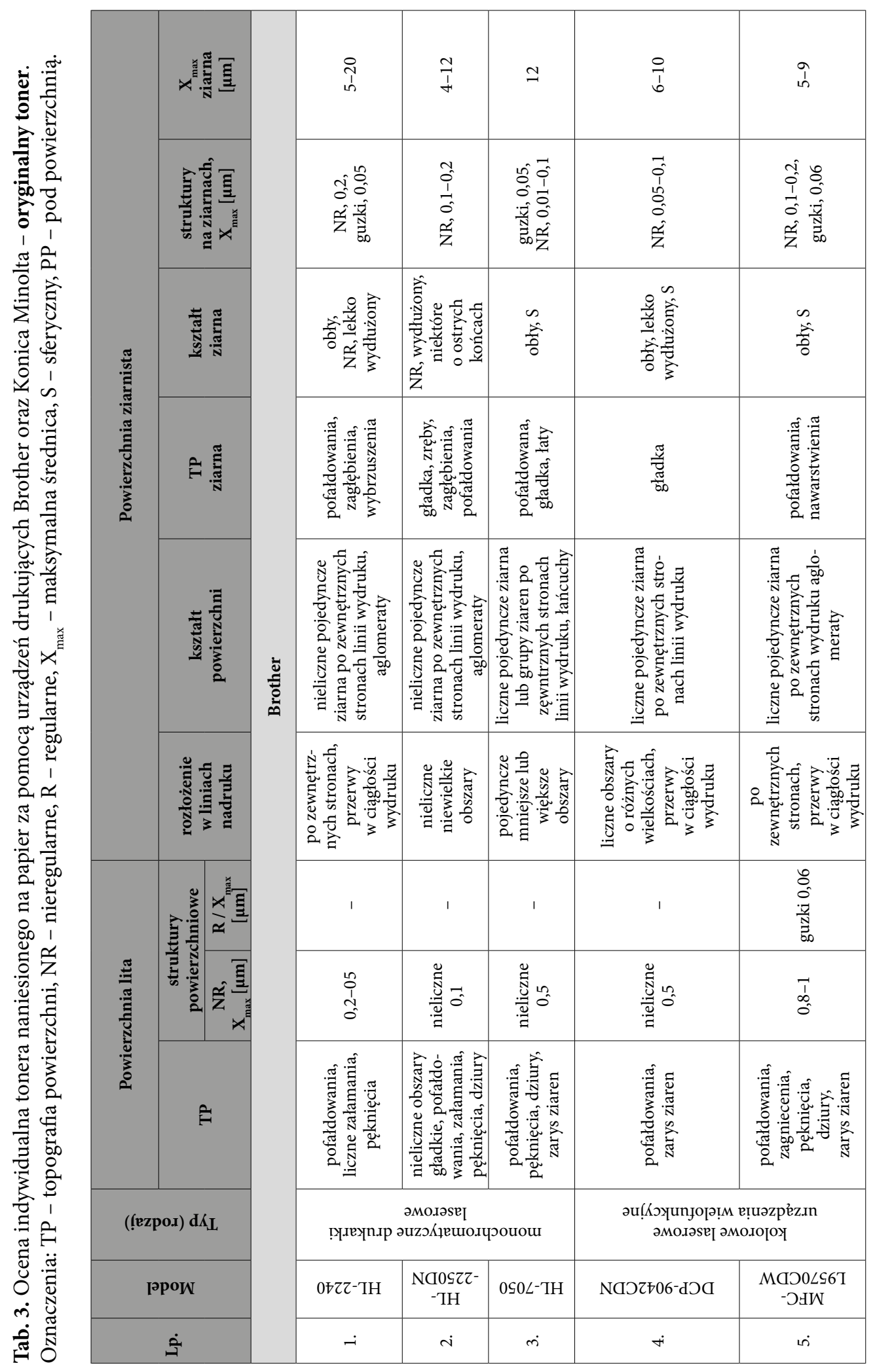




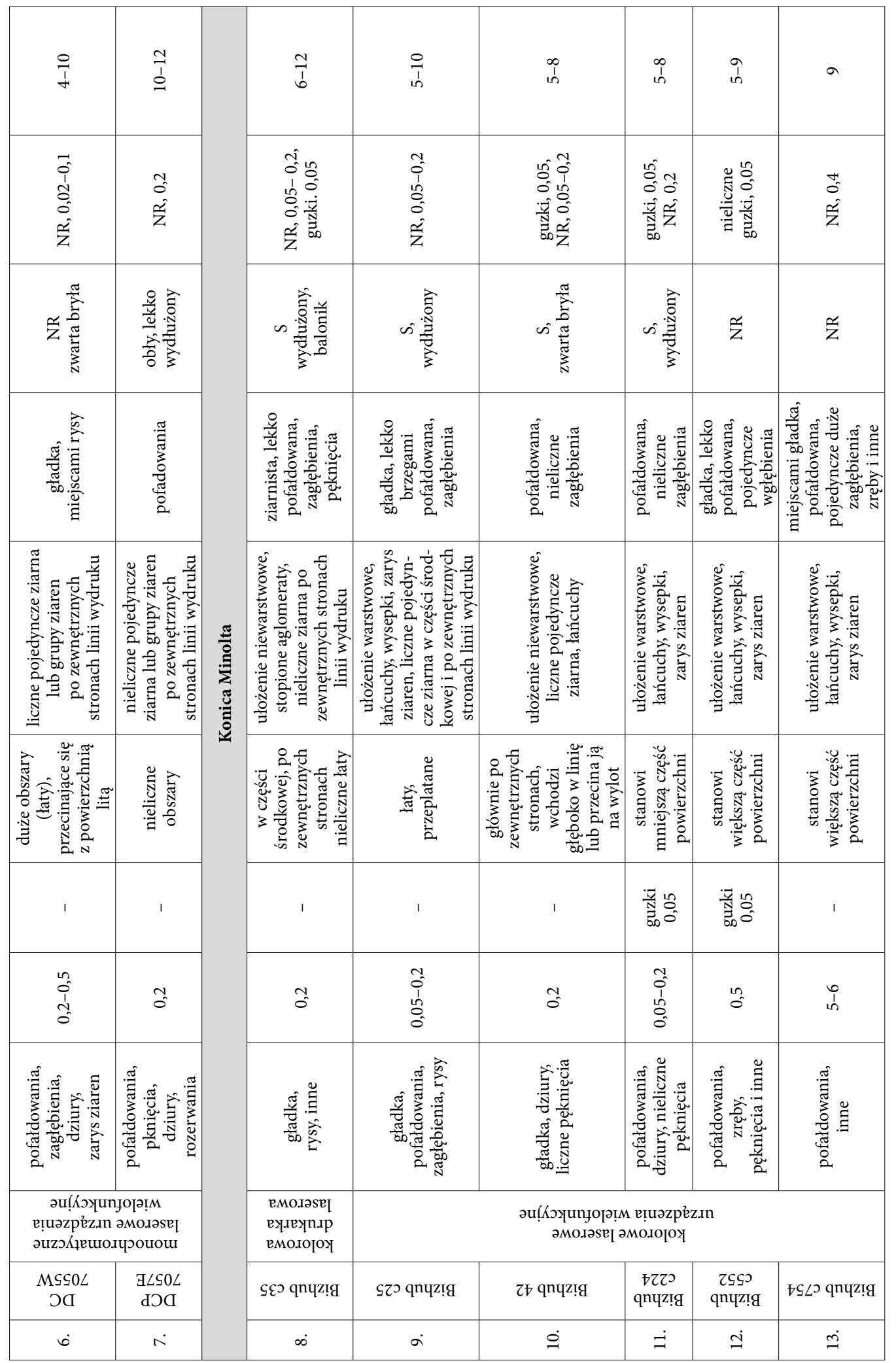




\begin{tabular}{|c|c|c|}
\hline$\underset{\substack{1 \\
1 \\
\text { in }}}{0}$ & $a$ & $\underset{1}{0}$ \\
\hline 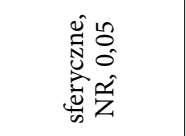 & 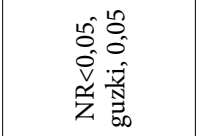 & 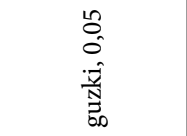 \\
\hline 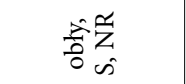 & 号 & 号 \\
\hline 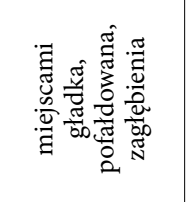 & 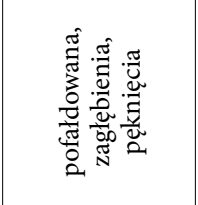 & 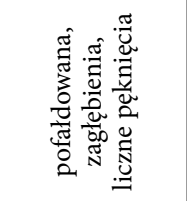 \\
\hline 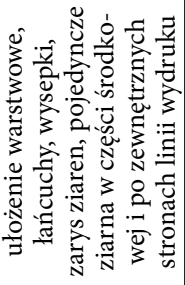 & 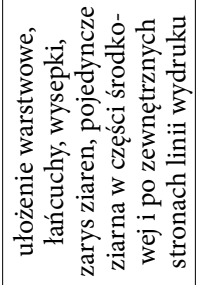 & 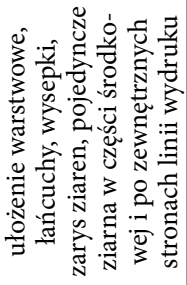 \\
\hline 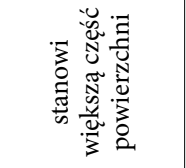 & 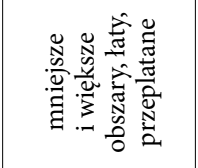 & 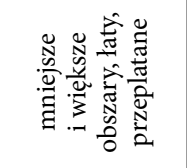 \\
\hline 1 & $\stackrel{20}{0}$ & 1 \\
\hline $\overrightarrow{0}$ & 1 & $\overrightarrow{0}$ \\
\hline 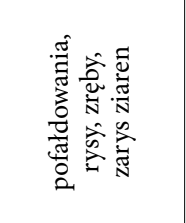 & 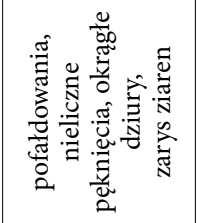 & 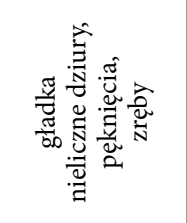 \\
\hline \multicolumn{3}{|c|}{ 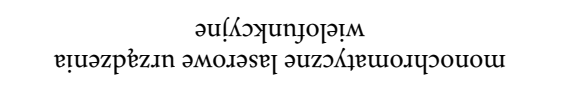 } \\
\hline દ8૪ qnчz!q & I0s qnyz!q & zss qnyz!̣ \\
\hline$\dot{I}$ & $\dot{n}$ & $\ddot{\ddots}$ \\
\hline
\end{tabular}




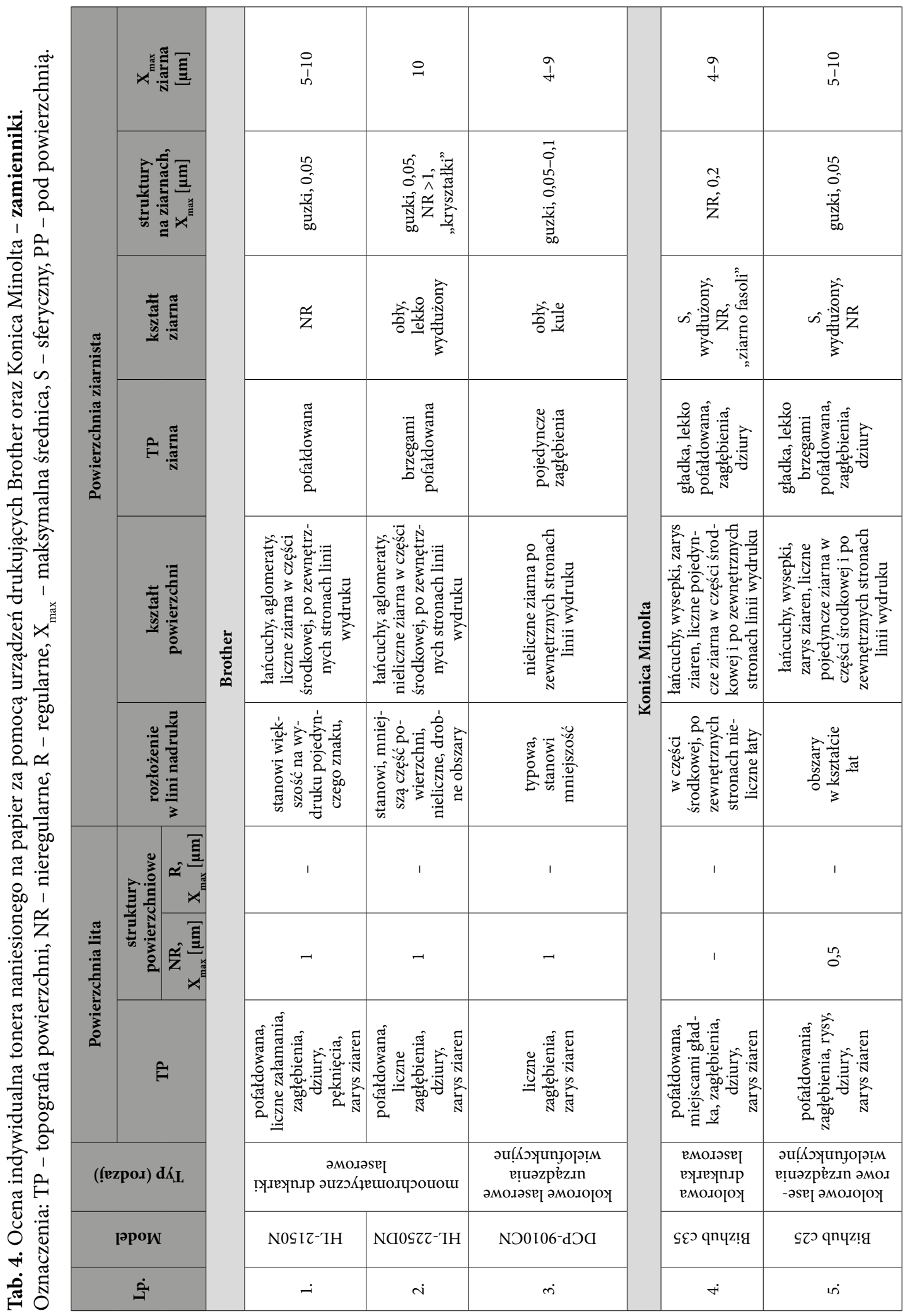




\section{Podsumowanie}

Do przeprowadzenia analizy tonerów wykorzystano wydruki uzyskane z 21 laserowych urządzeń drukujących dwóch różnych firm. Dało to możliwość identyfikacji tego typu urządzeń dzięki zastosowaniu grupowej i indywidualnej selekcji. Do badań wykorzystano oryginalne tonery oraz zamienniki. Na podstawie wcześniej ustalonych kryteriów ocenę cech charakterystycznych danego tonera na wydrukach przeprowadzono w taki sam sposób, jak opisano w części I ${ }^{6}$.

$\mathrm{Na}$ wydrukach zaobserwowano dwa rodzaje morfologiczne powierzchni tonera, tj. litą i ziarnistą. Warstwa lita była albo gładka i obejmowała całą powierzchnię nadruku, z nielicznymi pojedynczymi ziarnami widocznymi na jej linii brzegowej, albo przerywana licznymi lub pojedynczymi obszarami o różnym zagęszczeniu ziaren. Nie obserwowano powierzchni całkowicie ziarnistej.

$\mathrm{Na}$ żadnym badanym wydruku z obu firm nie zaobserwowano cech indywidualnych dla konkretnego tonera, takich jak pałeczki, igiełki, sześciany czy inne. Nie stwierdzono również cech charakterystycznych dla konkretnego typu urządzenia, jak na przykład nieregularnych lub kulistych struktur tuż pod powierzchnią ziarna i powierzchnią litą tonera, charakteryzujących się innym kontrastem na obrazie SEM. Tego typu struktury występowały w monochromatycznych drukarkach laserowych i monochromatycznych laserowych urządzeniach wielofunkcyjnych takich firm, jak Canon, Dell czy Lexmark ${ }^{7}$. Wykonano również badania oryginalnych tonerów na dwóch różnych podłożach papierowych, ale pochodzących od jednego producenta. Stwierdzono, że morfologia papieru miała wpływ na rozkład tonera na wydrukach oraz na ilość warstwy ziarnistej i litej. Nie zmieniała ona jednak cech wewnętrznych tonerów, tj. różnych struktur (guzików, struktur sferycznych, struktur nieregularnych o silnym kontraście fazowym) obecnych w samym tonerze.

Różnice między oryginalnymi tonerami a ich zamiennikami były widoczne głównie w kształtach ziaren i ich liczebności. W tym wypadku odróżnienie oryginalnego tonera od zamiennika jest dość trudne, również ze względu na zbyt małą liczbę cech szczególnych danego tonera. Dodatkowo zamienniki mogą różnić się od siebie w zależności od producenta, a nawet jeśli pochodzą od tego samego producenta. Przedstawione wyniki wstępnych badań przeprowadzonych na zamiennikach nie dają pewności co do jednoznaczności identyfikacji. Niemniej jednak badania morfologiczne oraz skład chemiczny zamienników pochodzących od różnych producentów są obecnie w fazie testów. Celem tych badań jest stworzenie bazy danych i opracowanie modelu przydatnego do klasyfikacji tonerów.

Na podstawie wykonanych badań oryginalnych kaset można stwierdzić, że tonery na wydrukach uzyskanych z urządzeń drukujących Brother i Konica Minolta charakteryzowały się dość dużym podobieństwem cech morfologicznych. Obserwacje

6 Zob. A. Łasińska, Analiza SEM czarnego tonera na wydrukach...

7 A. Łasińska, Assessment of the possibility...; taż, Analiza SEM czarnego tonera na wydrukach... 
mikroskopowe wskazały, że charakter morfologiczny tonerów stosowanych przez obie wyżej wymienione firmy był odmienny od cech charakterystycznych tonerów stosownych przez takie firmy, jak Lexmark, Canon czy Dell ${ }^{8}$. W przypadku tych ostatnich obecność indywidualnych lub grupowych cech ułatwia identyfikację konkretnego modelu lub grupy urządzeń. Brak istotnych różnic między tonerami obu firm w rezultacie uniemożliwia stwierdzenie, z jakiego urządzenia lub grupy urządzeń pochodzi wydruk.

Być może dobrym rozwiązaniem trudności związanych $\mathrm{z}$ identyfikacją cech charakterystycznych w oryginalnych tonerach stosowanych w urządzeniach drukujących Brother i Konica Minolta jest wykorzystanie niezwykle czułej analizy metodą spektroskopii Ramana ze wzmocnieniem powierzchniowym (ang. surface-enhanced Raman spectroscopy, SERS). Badania składu chemicznego za pomocą tej metody są obecnie w fazie testów.

\title{
Bibliografia
}

Kumar R., Samkaria A., Sharma V., On the spectroscopic cum chemometric approach for differentiation and classification of inkjet, laser and photocopier printed documents, „Science \& Justice" 2020, nr 4, s. 347-357.

Łasińska A., Analiza SEM czarnego tonera na wydrukach. Część I, „Przegląd Bezpieczeństwa Wewnętrznego" 2019, nr 21, s. 211-246.

Lasińska A., Assessment of the possibility of identification of black toners on printouts in Lexmark printers using SEM method, „Journal of Microscopy and Ultrastructure” 2018, nr 6, s. $145-159$.

Verma N. i in., On the spectroscopic examination of printed documents by using a field emission scanning electron microscope with energy-dispersive X-ray spectroscopy (FE-SEM-EDS) and chemometric methods: application in forensic science, "Analytical and Bioanalytical Chemistry" 2019, nr 411, s. 3477-3495.

\begin{abstract}
Abstrakt
Eksperci w zakresie badań dokumentów są często proszeni o określenie, czy wydruk pochodzi z określonej drukarki laserowej. Drukarkę rzadko można zidentyfikować, chyba że na wydruku są widoczne jej unikalne wady lub nieprawidłowości. W artykule przedstawiono możliwości identyfikacji i weryfikacji tonerów na wydrukach uzyskanych z różnych drukarek laserowych przy użyciu skaningowej mikroskopii elektronowej. W sumie 21 wydruków uzyskano z 21 różnych modeli maszyn drukujących
\end{abstract}

8 Tamże. 
Brother i Konica Minolta. Szesnaście wydruków uzyskano z drukarek, w których były oryginalne kasety z tonerem, a pięć z drukarek z zamiennikami. Ustalono jasne kryteria oceny indywidualnej. Na podstawie zdjęć SEM oraz tych kryteriów ujawniono szczegóły topografii struktury tonera. Na podstawie przeprowadzonych badań określono różnice lub podobieństwa tonerów na badanych wydrukach.

Słowa kluczowe: toner, Brother, Konica Minolta, skaningowa mikroskopia elektronowa, mikroanaliza rentgenowska, SEM/EDX.

\title{
SEM analysis of black toner on printouts. Part II
}

\begin{abstract}
Document examiners are frequently asked to determine whether or not a printout originated from a particular laser printer. The printer can rarely be identified unless some unique defects or irregularities of the printing are present on the printout. This article presents an overview of a systematic approach to characterizing and discriminating the toner of different laser printers using scanning electron microscopy. A total of twenty-one collected printouts were printed on twenty-one different Brother and Konica Minolta printing machine models. Sixteen printouts were obtained using printers with original toner cartridges while five printouts were obtained using printers with compatible cartridges. Clear criteria were established for individual assessment. Based on the SEM images and established criteria the details of topography of the toner structure were revealed. Due to this study, the differences or similarities of toners on tested printouts were determined. The SEM technique can be successfully, simply, and rapidly applied to the analysis of toners on paper documents.
\end{abstract}

Keywords: toner, Brother, Konica Minolta, scanning electron microscopy, X-ray microanalysis, SEM/EDX. 